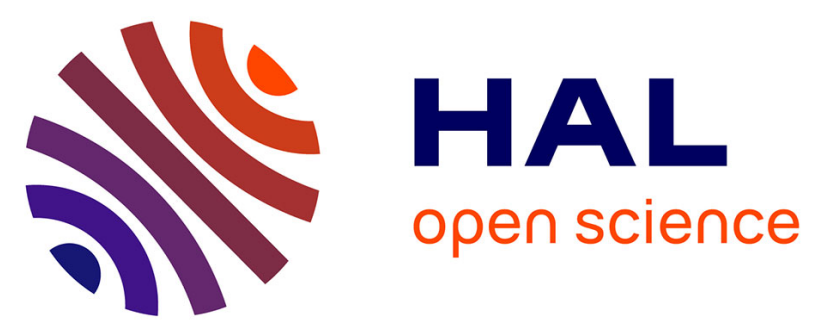

\title{
Gabbros from IODP Site 1256, equatorial Pacific: Insight into axial magma chamber processes at fast spreading ocean ridges
}

J. Koepke, Lyderic France, T. Mueller, F. Faure, N. Goetze, W. Dziony, Benoit Ildefonse

\section{To cite this version:}

J. Koepke, Lyderic France, T. Mueller, F. Faure, N. Goetze, et al.. Gabbros from IODP Site 1256, equatorial Pacific: Insight into axial magma chamber processes at fast spreading ocean ridges. Geochemistry, Geophysics, Geosystems, 2011, 12, pp.Q09014. 10.1029/2011GC003655 . hal-00644798

\section{HAL Id: hal-00644798 https://hal.science/hal-00644798}

Submitted on 7 Jan 2022

HAL is a multi-disciplinary open access archive for the deposit and dissemination of scientific research documents, whether they are published or not. The documents may come from teaching and research institutions in France or abroad, or from public or private research centers.
L'archive ouverte pluridisciplinaire HAL, est destinée au dépôt et à la diffusion de documents scientifiques de niveau recherche, publiés ou non, émanant des établissements d'enseignement et de recherche français ou étrangers, des laboratoires publics ou privés. 

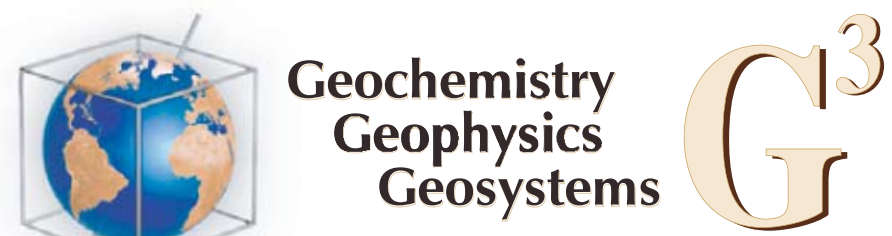

\title{
Gabbros from IODP Site 1256, equatorial Pacific: Insight into axial magma chamber processes at fast spreading ocean ridges
}

\author{
J. Koepke \\ Institut für Mineralogie, Leibniz Universität Hannover, Callinstrasse 3, D-30167 Hannover, \\ Germany (koepke@mineralogie.uni-hannover.de)
}

\section{France}

Centre de Recherches Pétrographiques et Géochimiques, UPR 2300, CNRS, Nancy Université, 15 rue Notre Dame des Pauvres, F-54501 Vandoeuvre lès Nancy, France

\section{T. Müller}

Institut für Mineralogie, Leibniz Universität Hannover, Callinstrasse 3, D-30167 Hannover, Germany

\section{F. Faure}

Centre de Recherches Pétrographiques et Géochimiques, UPR 2300, CNRS, Nancy Université, 15 rue Notre Dame des Pauvres, F-54501 Vandoeuvre lès Nancy, France

\section{N. Goetze and W. Dziony}

Institut für Mineralogie, Leibniz Universität Hannover, Callinstrasse 3, D-30167 Hannover, Germany

\section{B. Ildefonse}

Géosciences Montpellier, CNRS, Université Montpellier 2, CC60, F-34095 Montpellier CEDEX 05, France

[1] The ODP/IODP multileg campaign at ODP Site 1256 (Cocos plate, eastern equatorial Pacific) provides the first continuous in situ sampling of fast spreading ocean crust from the extrusive lavas, through the sheeted dikes and down into the uppermost gabbros. This paper focuses on a detailed petrographic and microanalytical investigation of the gabbro section drilled during IODP Expedition 312. The marked patchy and spotty features that can be observed in many Hole 1256D gabbros is mostly due to a close association of two different lithological domains in variable amounts: (1) subophitic domains and (2) a granular matrix. Major and trace element mineral compositions, geothermometry, and petrological modeling suggest that subophitic and granular domains follow one single magma evolution trend formed by in situ fractionation. The subophitic domains correspond to the relative primitive, high-temperature end-member, compositionally similar to the basalts and dikes from the extrusive unit upsection, while the granular domains fit with a magma evolution by crystal fractionation to lower temperatures, up to a degree of crystallization of $\sim 80 \%$. Our results support the following scenario for the fossilization of the axial melt lens at ODP Site 1256: relatively primitive MORB melts under near-liquidus conditions fill the melt lens and feed the upper, extrusive crust. Near the melt lens-sheeted dike boundary at lower temperatures, crystallization starts with first plagioclase before clinopyroxene in a mushy zone forming the subophitic domains. At decreasing temperatures, the subophitic domains continue to crystallize, finally forming a well-connected framework. Evolved, residual melt is finally trapped within the subophitic network, crystallizing at near-solidus conditions to the granular matrix. Another important textural feature in Hole 1256D gabbros is the presence of 
microgranular domains which are interpreted as relics of stoped/assimilated sheeted dikes (transformed to "granoblastic dikes" by contact metamorphism). All these different domains can be observed in close association, often at the thin section scale, demonstrating the extremely complex petrological record of combined crystallization/assimilation processes ongoing in the axial melt lens. Very similar gabbros with a marked spotty/patchy appearance, and bearing the same close association of lithological domains as observed at Site 1256, are known in the so-called "varitextured gabbro" unit from the Oman Ophiolite located at the same structural level, between cumulate gabbros and granoblastic dikes. The close petrological similarity of the gabbro/dike transition between both IODP Hole 1256D and the Oman ophiolite suggests that in situ fractionation and dike assimilation/contamination are major magmatic processes controlling the dynamics and fossilization of the axial melt lens at fast spreading oceanic ridges.

Components: 21,800 words, 8 figures, 4 tables.

Keywords: Mid-Atlantic Ridge; axial melt lens; fractional crystallization; gabbro; magma chamber processes.

Index Terms: 1012 Geochemistry: Reactions and phase equilibria (3612, 8412); 1032 Geochemistry: Mid-oceanic ridge processes (3614, 8416); 3625 Mineralogy and Petrology: Petrography, microstructures, and textures.

Received 15 April 2011; Revised 19 July 2011; Accepted 21 July 2011; Published 22 September 2011.

Koepke, J., L. France, T. Müller, F. Faure, N. Goetze, W. Dziony, and B. Ildefonse (2011), Gabbros from IODP Site 1256, equatorial Pacific: Insight into axial magma chamber processes at fast spreading ocean ridges, Geochem. Geophys. Geosyst., 12, Q09014, doi:10.1029/2011GC003655.

\section{Introduction}

\subsection{IODP Hole 1256D}

[2] Ocean Drilling Program (ODP) Site 1256 is located in the eastern equatorial Pacific on $15 \mathrm{Ma}$ oceanic crust of the Cocos plate formed at the East Pacific Rise (EPR) under superfast spreading rate (220 mm/yr, full spreading rate). Hole 1256D, initiated by ODP Leg 206 and continued by IODP Expeditions 309 and 312 penetrated the entire upper oceanic crust, passing through a $\sim 250 \mathrm{~m}$ thick sediment sequence, a $\sim 800 \mathrm{~m}$ thick lava series and a relatively thin, $\sim 350 \mathrm{~m}$ thick sheeted dike complex before finally extending $\sim 100 \mathrm{~m}$ into the uppermost gabbros [Teagle et al., 2006; Wilson et al., 2006]. Hole $1256 \mathrm{D}$ is the first complete penetration of the upper oceanic crust reaching the gabbroic section, and represents a unique reference section for the dike/gabbro transition in fast spreading ocean crust. Initial drilling results from Site 1256, together with site maps and details on the geological setting and the observed lithostratigraphic units are given by Teagle et al. [2006, 2007].

[3] Of special interest was the observation [Teagle et al., 2006] of a $\sim 60 \mathrm{~m}$ thick zone of the lowermost sheeted dikes, directly above the plutonic section, with hornfelsic appearance interpreted as resulting from contact metamorphism with a strong metamorphic gradient toward the contact with gabbro contact, forming the so-called "granoblastic dikes." Koepke et al. [2008] and Alt et al. [2010] quantified the temperature conditions of the metamorphic overprint in the granoblastic dikes, and proposed that this zone corresponds to a thermal conductive boundary layer between the active magma system of the melt lens and the lowtemperature, convective hydrothermal system within the sheeted dike section. All observed features in the root zone of the sheeted dikes, i.e., contact "hornfels" metamorphism of the lowermost dikes, partial melting triggered by water-rich fluids, highly heterogeneous isotropic gabbros ("varitextured" gabbros), and complex intrusive relationships, have been documented at the same crustal level in the Troodos ophiolite [Gillis and Roberts, 1999; Gillis and Coogan, 2002], in the Oman ophiolite [France et al., 2009b], and at Hess Deep near the EPR [Gillis, 2008]. The combined results of these studies support a model in which magmatic systems at fast spreading ridges are very dynamic, with an axial melt lens that may move up and down [e.g., Hooft et al., 1997; Lagabrielle and Cormier, 1999; Garel et al., 2002; Gillis and Coogan, 2002; Gillis, 2002; Karson et al., 2002; Coogan et al., 2003; Gillis, 2008; France et al., 2009b]. Hole 1256D provides the first in situ access for detailed petrological and geochemical investigation of this geochemically critical zone. It was shown that the solidus temperature for hydrothermally altered dikes is as low as $850^{\circ} \mathrm{C}$ 


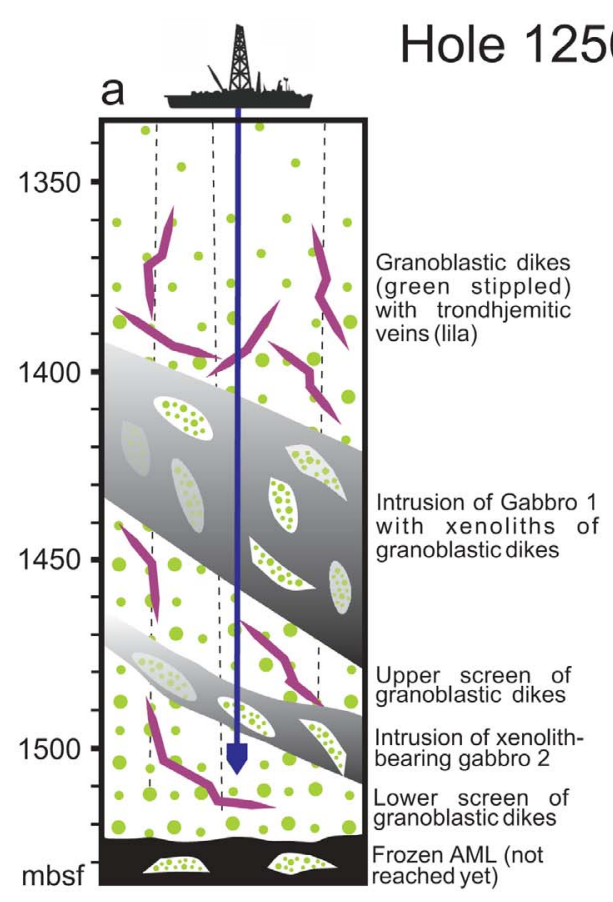

Wilson et al. [2006]; Teagle et al. [2006]; Koepke et al. [2008]; Alt et al. [2010]

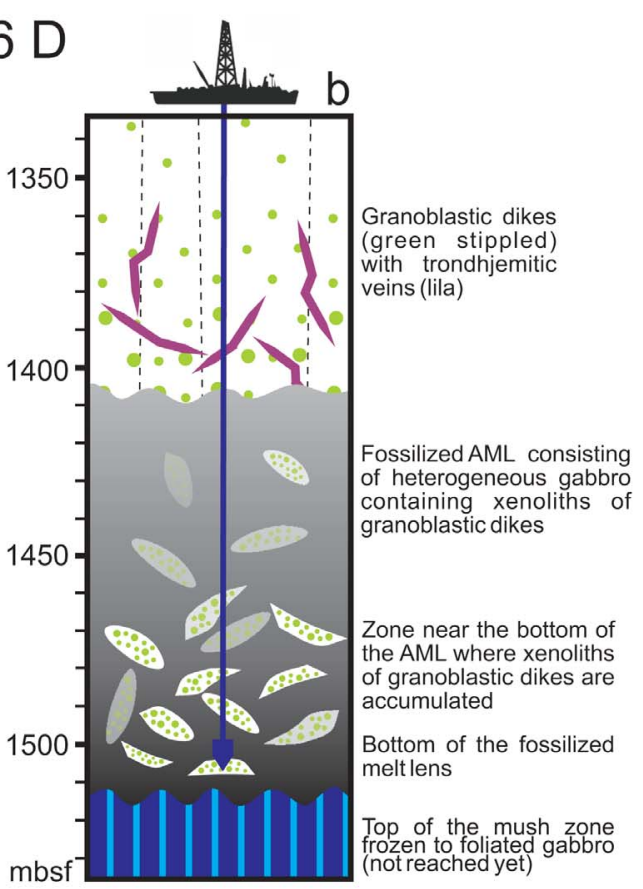

France et al. [2009]

Figure 1. Cartoons illustrating the dike/gabbro transition at ODP Site 1256 drilled by IODP Expedition 312, as interpreted by different authors. The location of the drill core is indicated in blue. Both cartoons reproduce the lithostratigraphy recorded in the drill core of Hole 1256D as presented by Teagle et al. [2006]. The size of the fragments of granoblastic dikes observed in the gabbros is out of scale; see text for further details. For clarity, the lowermost rock recovered from Hole 1256D by Expedition 312, a basaltic dike that lacks granoblastic textures, which is interpreted to be a late dike crosscutting the gabbros [Teagle et al., 2006], is not included into the cartoon. Green stippled, granoblastic dikes; lilac, trondhjemitic veins; gray, Gabbros 1 and 2; black, frozen axial melt lens; blue striped, foliated gabbro.

[France et al., 2010]. For the rocks drilled at Site 1256, two pyroxene equilibrium temperatures for the lowermost dikes range between $850^{\circ} \mathrm{C}$ and $1050^{\circ} \mathrm{C}$ [Koepke et al., 2008; Alt et al., 2010], implying that conditions within the granoblastic zone were appropriate for hydrous anatexis, with the potential to generate partial melts of trondhjemitic composition. The downhole evolution of the granoblastic overprint is expressed by systematic changes in texture, phase composition and calculated equilibrium temperature, consistent with thermal metamorphism by a deeper heat source. Simple thermal modeling performed by Koepke et al. [2008] and Coggon et al. [2008] implies a long-lasting heat source located beneath the granoblastic dikes, potentially consistent with a steady state, high-level axial magma chamber (AMC) located at the base of the sheeted dike section.

[4] The recovered gabbroic section below the granoblastic dikes was initially interpreted to be composed of two individual intrusions (named "Gabbro 1 " and "Gabbro 2") separated by a screen of grano- blastic dikes ("Upper Dike Screen") and underlain by another horizon of granoblastic dikes ("Lower Dike Screen") as depicted in Figure 1a [Teagle et al., 2006; Wilson et al., 2006; Koepke et al., 2008; Alt et al., 2010]. Investigations in sections displaying the dike/gabbro transition in the Oman ophiolite revealed petrographic and structural features very similar to those described in Hole 1256D [France et al., 2009b]. In a comparative petrographical and geochemical study, France et al. [2009b] tentatively reinterpreted the drilled gabbro section at Site 1256 as one continuous gabbro body representing the fossilized axial melt lens, where the upper and the lower dike screens correspond to stoped blocks of partially resorbed granoblastic dikes, which were preferentially accumulated in the lower part of the axial melt lens (Figure 1b).

[5] This paper focuses on a detailed petrographic and microanalytical (major and trace elements) investigation of the gabbro section drilled during IODP Expedition 312. This study builds on the shipboard petrographical work and postcruise 
Table 1. Samples From the Drill Core of Hole 1256D Used in This Study

\begin{tabular}{|c|c|c|c|c|c|c|c|c|c|c|}
\hline $\operatorname{Exp}^{a}$ & Core & $\mathrm{Sc}^{\mathrm{b}}$ & $\begin{array}{l}\text { Top } \\
(\mathrm{cm})\end{array}$ & $\begin{array}{l}\text { Bottom } \\
\text { (cm) }\end{array}$ & Piece & $\begin{array}{l}\text { Depth } \\
\text { (mbsf) }\end{array}$ & Unit & Lithology & $\begin{array}{c}\text { Thin } \\
\text { Section }^{\mathrm{c}}\end{array}$ & Description $^{\mathrm{d}}$ \\
\hline 312 & 214 & 2 & 0 & 6 & 1 & 1412.4 & 84 & Gabbro 1 & 63 & 2142006 \\
\hline 312 & 214 & 2 & 15 & 17 & $4 a$ & 1412.5 & 84 & Gabbro 1 & 69 & $214^{-} 2-1 \overline{5} \quad 17$ \\
\hline 312 & 215 & 1 & 84 & 88 & 17 & 1416.5 & 85 & Gabbro 1 & 71 & 21518488 \\
\hline 312 & 215 & 2 & 12 & 14 & 3 & 1417.3 & 85 & Gabbro 1 & - & $215-2-12-14$ \\
\hline 312 & 217 & 1 & 4 & 9 & 2 & 1421.6 & 87 & Gabbro 1 & - & $217104-09$ \\
\hline 312 & 218 & 1 & 41 & 44 & 10 & 1425.7 & 88 & Gabbro 1 & - & $218-41-44$ \\
\hline 312 & 220 & 1 & 52 & 57 & 9 & 1435.5 & 88 & Gabbro 1 & - & $220-15257$ \\
\hline 312 & 221 & 1 & 30 & 32 & 7 & 1439.9 & 88 & Gabbro 1 & - & 221 \\
\hline 312 & 223 & 1 & 43 & 48 & 8 & 1449.7 & 88 & Gabbro 1 & - & 22314348 \\
\hline 312 & 223 & 2 & 33 & 37 & 1 & 1451.1 & $89 \mathrm{~A}$ & Gabbro 1 & - & $223 \quad 2 \quad 33 \quad 37$ \\
\hline 312 & 223 & 2 & 57 & 60 & 1a & 1451.4 & $89 \mathrm{~A}$ & Gabbro 1 & 93 & 223_2_57_60 \\
\hline 312 & 223 & 3 & 1 & 6 & 1 & 1452.3 & $89 \mathrm{~A}$ & Gabbro 1 & 95 & $223 \_3 \_1 \_6$ \\
\hline 312 & 225 & 1 & 4 & 8 & 2 & 1458.9 & $90 \mathrm{~A}$ & Up. Dike screen & - & 225148 \\
\hline 312 & 225 & 1 & 10 & 14 & 3 & 1459.0 & $90 \mathrm{~A}$ & Up. Dike screen & - & $225-2-10$ \\
\hline 312 & 226 & 1 & 4 & 6 & 2 & 1463.9 & $90 \mathrm{~A}$ & Up. Dike screen & - & $226-4 \overline{6}$ \\
\hline 312 & 227 & 1 & 23 & 28 & $5 \mathrm{a}$ & 1468.7 & $90 \mathrm{~A}$ & Up. Dike screen & 100 & $227^{-} 1-2 \overline{3} 28$ \\
\hline 312 & 227 & 1 & 30 & 34 & $6 \mathrm{~b}$ & 1468.8 & $90 \mathrm{~A}$ & Up. Dike screen & - & $227-30 \quad 34$ \\
\hline 312 & 230 & 1 & 54 & 56 & 8 & 1483.5 & $91 \mathrm{~A}$ & Gabbro 2 & - & 23015456 \\
\hline 312 & 230 & 2 & 36 & 40 & $6 b$ & 1484.9 & $91 \mathrm{~A}$ & Gabbro 2 & 110 & $230-3640$ \\
\hline 312 & 232 & 1 & 82 & 85 & - & 1493.7 & $91 \mathrm{~A}$ & Gabbro 2 & - & 23218285 \\
\hline 312 & 232 & 1 & 97 & 100 & $5 c$ & 1493.9 & $91 \mathrm{~A}$ & Gabbro 2 & 113 & $232197-100$ \\
\hline 312 & 232 & 2 & 52 & 54 & 2 & 1494.5 & 93 & Gabbro 2 & 115 & $232-25254$ \\
\hline 312 & 232 & 2 & 98 & 100 & 9 & 1495.0 & $93 / 94$ & Gabbro 2 & 116 & $232298 \quad 100$ \\
\hline 312 & 233 & 1 & 8 & 12 & 1 & 1497.6 & 94 & Low. Dike screen & - & $233+18-12$ \\
\hline 312 & 233 & 1 & 14 & 18 & 2 & 1497.6 & 94 & Low. Dike screen & - & 233114 \\
\hline
\end{tabular}

detailed mineral composition analyses, in an attempt to decipher the complex magmatic processes occurring at this key level for oceanic crust accretion.

\subsection{Methods}

[6] Sample names are shortened from the original IODP nomenclature (Table 1). Petrographic features of the investigated samples are given in Table 2. Some shipboard thin sections were carefully reinvestigated including a very detailed microanalytical survey. Initial individual descriptions of the analyzed thin sections are given by Teagle et al. [2006], including detailed information about structural and metamorphic features, estimates of the modal amounts of primary and secondary minerals, and presentation of photomicrographs. The numbers of those figures of Teagle et al. [2006] presenting petrographic details of samples used in this study are included in Table 2. The core recovery during Expedition 312 was extremely heterogeneous. While the recovery of the sheeted dike complex was very poor $(<12 \%)$, the recovery improved significantly when entering the plutonic unit with an average value of $\sim 40 \%$ [Teagle et al., 2006]. Thus, in spite of the overall relatively low recovery, we assume that the results presented in this paper, based on 25 samples, are representative of the plutonic section of Site 1265D. In addition, the gabbros at Site $1256 \mathrm{D}$ are petrologically very heterogeneous, often containing 2 or more different lithological domains in a single thin section (see below). It was our attempt to perform complete mineral analyses of each domain, which expands the number of analyzed individual lithological units to 46 (based on more than 3000 single point electron microprobe analyses; for details see Tables 2 and 3 and more than 300 laser ablation ICP-MS trace element analyses).

[7] Electron probe microanalyses (EPMA) were performed using a Cameca SX100 electron microprobe equipped with 5 spectrometers and an operating system "Peak sight" (Institut für Mineralogie, Hannover, Germany). All data were obtained using $15 \mathrm{kV}$ acceleration potential, a static (fixed) beam, $\mathrm{K} a$ emission from all elements, and the "PAP" matrix correction [Pouchou and Pichoir, 1991]. Most element concentrations were obtained with a beam current of $15 \mathrm{nA}$ and a counting time of $20 \mathrm{~s}$ on peak and background. For $\mathrm{Cl}$ and $\mathrm{F}$ measurement in 


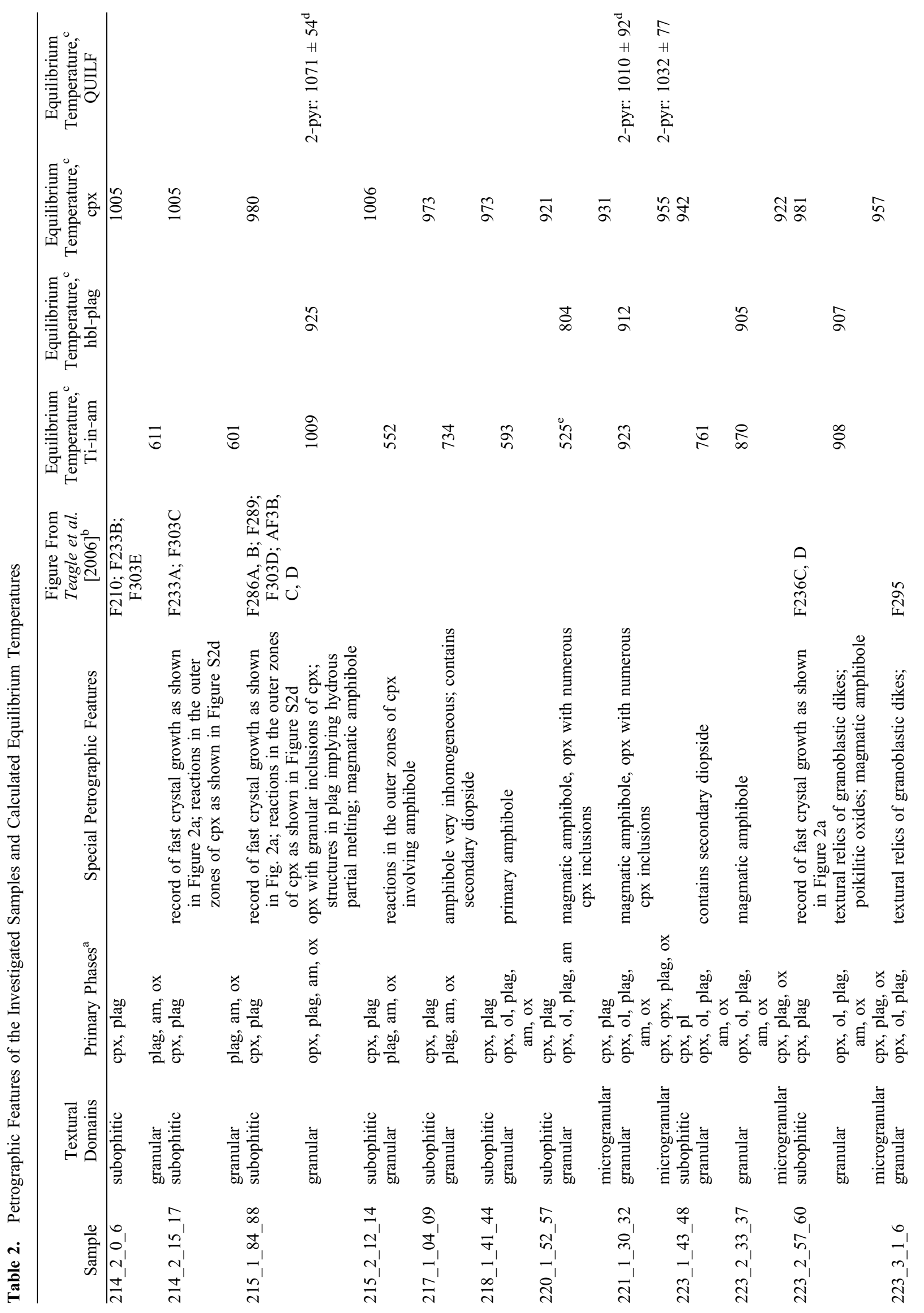




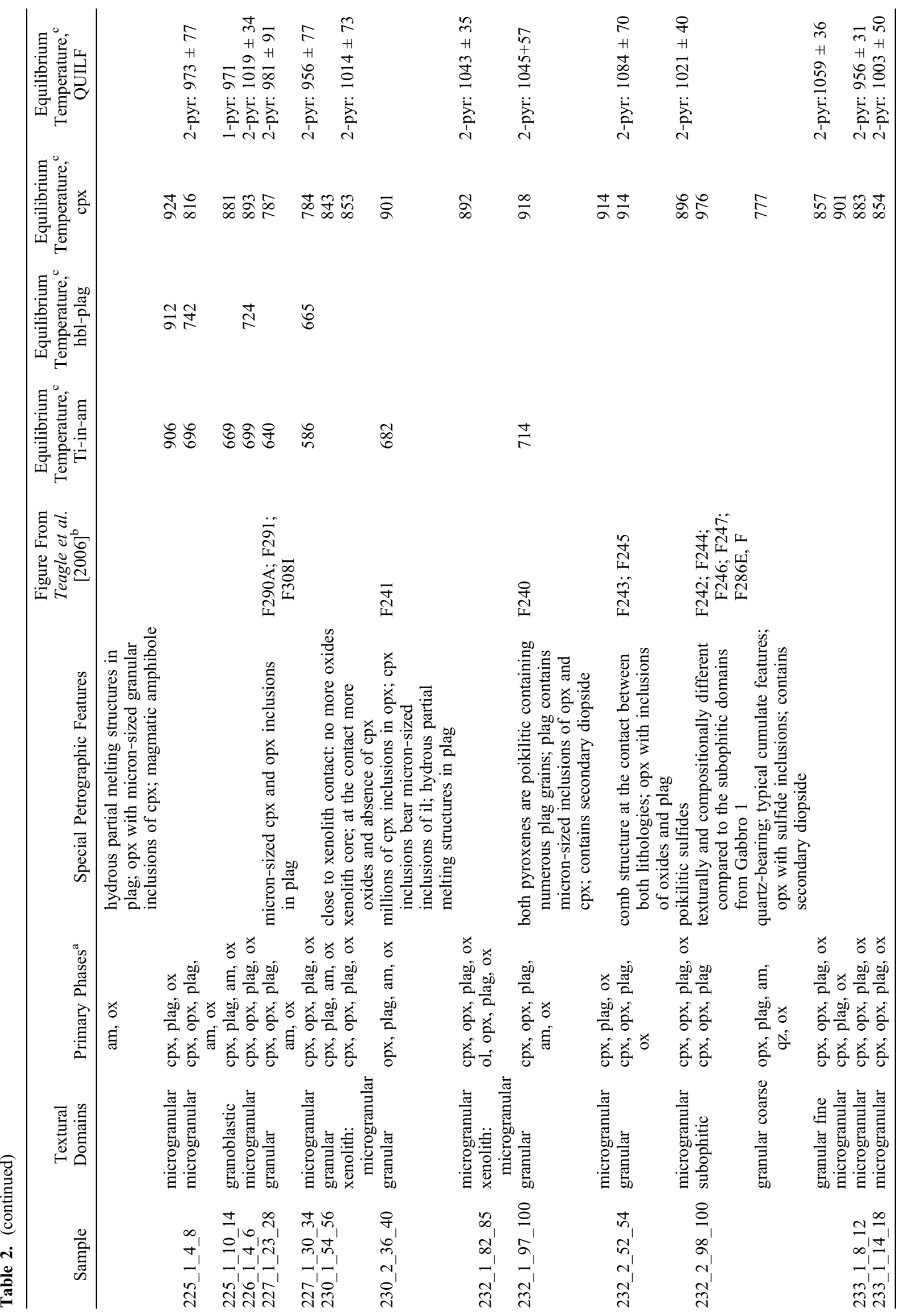


amphibole and for some trace elements in plagioclase ( $\mathrm{Ti}, \mathrm{Mg}, \mathrm{K})$ measured along profiles, the counting time was increased to 60 to $120 \mathrm{~s}$ leading to more accurate trace element data and lower limits of detection. Average results are presented in Table 3. For comparison, some diagrams also include mineral compositions from lavas and dikes of the upper section [Dziony et al., 2008; Yamazaki et al., 2009], and from the lower dike screen [Yamazaki et al., 2009].

[8] We used several independent geothermometers to estimate equilibrium temperatures. The 2-pyroxene thermometer ("QUILF" [Andersen et al., 1993]) could only be used in lithological domains with coexisting clinopyroxene and orthopyroxene, a case which is not seen in most gabbros. As expressed in Table 2, the QUILF thermometer is mostly used for microgranular patches within the gabbros, but only rarely in subophitic domains representing the record of the main stage crystallization. Single pyroxene thermometry with QUILF is in principle possible, but was not applied in this study due to very high errors in temperature estimates $\left(>150^{\circ} \mathrm{C}\right)$. Therefore, we also used the single clinopyroxene thermometer of France et al. [2010], especially in those lithological domains were only clinopyroxene without coexisting orthopyroxene was present. We assume that the application of this tool is appropriate, since the boundary conditions for the calibration experiments are met: low pressure, hydrous conditions, and a MORB-type system (hydrothermally altered basalts from the Oman ophiolite). For a detailed discussion on the usage of the geothermometers see sections 3.1.2 and 4.2.1.

[9] For amphibole-bearing parageneses we used the amphibole-plagioclase thermometer of Holland and Blundy [1994], and the semiquantitative Ti-inamphibole thermometer of Ernst and Liu [1998], which is applicable since all amphiboles except in one case coexist with a high Ti phase (ilmenite). The benefit of the latter thermometer is that it could be also applied to those amphiboles where the corresponding equilibrium plagioclase composition is not clear (e.g., in the granular lithological domain where primary amphiboles mostly occur as cores in hydrothermally altered rims). The reli- ability of the Ti-in-amphibole thermometer for the application in hydrous tholeiite system equilibrated at low pressure was confirmed in experimental studies [Koepke et al., 2003, 2004] and in studies on natural gabbros [e.g., Koepke et al., 2005a].

[10] Trace element analyzes were performed in situ on polished thin sections ( $150 \mu \mathrm{m}$ thick). Laser ablation trace elements determinations were performed at the Laboratory Magmas et Volcans of Clermont-Ferrand (France) using a Resonetics Resolution M-50 powered by an ultra short pulse ATL Atlex Excimer laser system operating at a wavelength of $193 \mathrm{~nm}$ (a detailed description is given by Müller et al. [2009]) coupled to an Agilent $7500 \mathrm{cs}$ ICP-MS. Ablation was performed in pure $\mathrm{He}$ atmosphere, and the ablated particles were transferred from the cell to the plasma by a $\mathrm{N}$ and Ar gas stream. Data were acquired using a 33 to $73 \mu \mathrm{m}$ diameter spot depending on the samples, pulsing the laser at $4 \mathrm{~Hz}(6 \mathrm{mj})$, and producing an energy density on the sample corresponding to $\sim 15 \mathrm{~J} / \mathrm{cm}^{2}$. The acquisition time was $90 \mathrm{~s}$, with $\sim 30 \mathrm{~s}$ of the signal being dedicated to background measurement. For trace element determinations, each run began and finished with three analyses of the NIST Standard Reference Material 612 [Gagnon et al., 2008] followed by two analyses of BCR2G basalt glass standard [Gagnon et al., 2008] with $\sim 15$ unknowns in between. The concentrations were determined relative to ${ }^{29} \mathrm{Si}$ for orthopyroxene and to ${ }^{44} \mathrm{Ca}$ for clinopyroxene and plagioclase. The analytical uncertainties for all measured elements are estimated to be better than $5 \%$ at the $95 \%$ confidence level. Data reduction was carried out with the software package GLITTER (Macquarie Research Ltd) [Van Achterberg et al., 2001].

\section{Petrography of the Gabbro Section}

\subsection{Primary Magmatic Features}

\subsubsection{General Characteristics}

[11] The plutonic rocks from Hole 1256D span a wide range of compositions covering gabbros, oxide

\footnotetext{
Notes to Table 2:

${ }^{a}$ Abbreviations are as follows: cpx, clinopyroxene; opx, orthopyroxene; ol, olivine; plag, plagioclase; am, amphibole; qz, quartz; ox, oxides; il, ilmenite.

${ }^{\mathrm{b}}$ Number of figure from Teagle et al. [2006] in which petrographic details of the corresponding samples are presented.

${ }^{\mathrm{c}}$ Equilibrium temperatures were calculated with the following geothermometers (see references and text for details): For TiO ${ }_{2}$-in-amphibole, for those domains containing different amphibole population, only that corresponding to higher temperatures was chosen. For amphibole-plagioclase, thermometry was only applied to those amphiboles with assumed primary composition. The temperature of cpx was calculated with a single thermometer according to France et al. [2010]. Abbreviations 1-pyr and 2-pyr indicate QUILF single- and two-pyroxene thermometer.

${ }^{\mathrm{d}}$ Equilibrium temperature calculated for orthopyroxene host and clinopyroxene inclusions.

'Ti-in-amphibole temperature too low due to the absence of a coexisting $\mathrm{TiO}_{2}$-bearing oxide phase.
} 
Table 3 (Sample). Mineral Compositions ${ }^{\mathrm{a}}$ [The full Table 3 is available in the HTML version of this article]

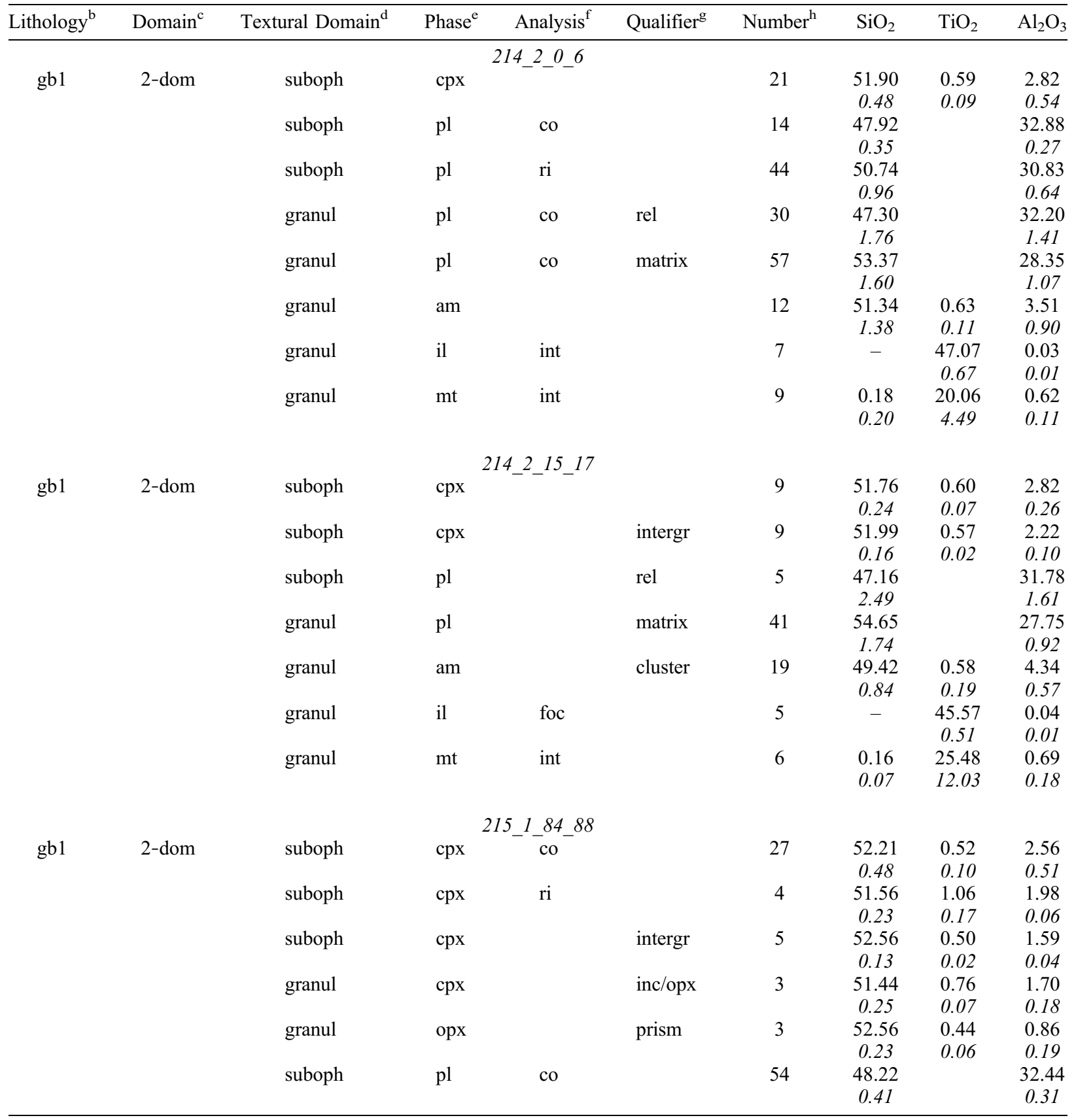

${ }^{\mathrm{a}}$ Dashes indicate below limit of detection, empty space indicates not analyzed, $\mathrm{FeO}=\mathrm{FeO}$ tot, and italic values indicate one standard deviation.

${ }^{\mathrm{b}}$ Lithology: gb1, Gabbro 1; gb2, Gabbro 2; Udi-s, upper dike screen; Ldi-s, lower dike screen.

${ }^{\mathrm{c}}$ Domains: number of identified textural/lithological domains; gb/xeno, gabbro hosting a xenolith; xeno, xenolith.

${ }^{\mathrm{d}}$ Textural domain: coarse, granular coarse-grained; fine, granular fine-grained; granbl, granoblastic; granul, granular; m granul, granular matrix hosting xenolith; $m$ granul(-), granular matrix near the contact to a xenolith without oxides; microgran, microgranular; suboph, subophitic; xeno core, core region of a xenolith; xeno rim, rim of a xenolith; xeno, xenolith.

ePhase: am, amphibole; cpx, clinopyroxene; il, ilmenite; mt, magnetite; ol, olivine; opx, orthopyroxene; pl, plagioclase.

f Details of the analysis: co, core; ri, rim; empty space, central part of the crystal. For oxides, foc, focused analyzed; int, integral analyzed.

${ }^{g}$ Phase qualifier: Ab-rich and An-rich, Ab- and An-enriched zone in partial molten plagioclase; cluster, phase arranged in cluster; diop, diopsidic clinopyroxene; exsol, exsolutions; flaky, flaky habit; host, host crystal bearing exsolutions; image, calculated composition via image analysis; inc/ opx and inc/plag, tiny inclusions in orthopyroxene and plagioclase, respectively; intergr, intrgrowth formed by reaction; matrix, matrix phase; out rim, outermost rim; poik, poikilitic; poikbl, poikiloblastic; pop1, population 1; pop2, population 2; prism, prismatic; rel, An-rich relict. For details see text.

${ }^{\mathrm{h}}$ Number of analyses.

${ }^{\mathrm{i}} \mathrm{MgO} /(\mathrm{MgO}+$ FeOtot $) * 100$, molar.

${ }^{\mathrm{j}} \mathrm{An}$ content of the plagioclase, mol \%. 
gabbros, orthopyroxene-bearing gabbros, olivinebearing gabbros, and highly differentiated rocks like quartz-rich oxide diorites and trondhjemite dikelets. Detailed petrographic descriptions of the different gabbroic units as well as of the upper and lower dike screens are given by Teagle et al. [2006]. Bulk analyses of $1256 \mathrm{D}$ gabbros revealed that these are in average slightly less fractionated than the basalts and dikes from the extrusive section [Wilson et al., 2006]. However, with an average $\mathrm{Mg} \#(\mathrm{Mg} \#=$ $\mathrm{MgO} /(\mathrm{MgO}+\mathrm{FeO})^{*} 100$; in molar proportions) of 60.3 , the average gabbro composition is too evolved to correspond to a primary mantle melt which should have a Mg \# of 70-78 [Teagle et al., 2006; Wilson et al., 2006]. Olivines observed in Hole 1256D gabbros are relatively iron-rich (forsterite content ranging from 62 to 68; this study), and coexist with orthopyroxene and oxide often in the absence of clinopyroxene. They do not correspond to the primitive olivines of olivine gabbros that are typical for the lower oceanic crust from fast spreading ridges (see review by Coogan [2007]). Typical "foliated gabbros" where constituent minerals show in general a steep magmatic foliation observed in a high crustal level from Hess Deep [e.g., MacLeod et al., 1996] or Pito Deep [Perk et al., 2007] at the EPR, or in the Oman ophiolite (subparallel to the sheeted dykes [MacLeod and Yaouancq, 2000; Nicolas et al., 2008; France et al., 2009b; Nicolas et al., 2009]), were not recovered. Based on a detailed structural and petrogeochemical comparison between IODP Hole 1256D samples and results obtained in the Oman ophiolite, France et al. [2009b] proposed that the foliated gabbros representing the main magma chamber lie only tens of meters below the hole bottom of Site 1256D (Figure 1b). Compared to the Oman ophiolite, the recovered gabbros at Site 1256 show some similarities with the uppermost gabbro horizon, directly below the sheeted dikes, often named "varitextured gabbro" [e.g., Lippard et al., 1986; MacLeod et al., 2002; Nicolas et al., 2008], a 50 to $200 \mathrm{~m}$ thick horizon characterized by extreme variability in texture, grain size and chemical composition, generally lacking any foliation.

[12] A key feature of the $1256 \mathrm{D}$ gabbros is the strong variation in mineralogy and texture at the $\mathrm{mm}$ to $\mathrm{cm}$ scale, expressed by a marked patchiness and spotty appearances in many gabbros [Teagle et al., 2006], and detailed in the next section. Detailed petrographic investigations revealed that this is mostly due to different domains closely associated, representing different types of gabbro, mostly also contrasting in texture. Best examples for very patchy rocks are represented by Gabbro 1 , where locally two domains of different lithologies are intimately mixed together: centimeter-sized spots of gabbro composed only of plagioclase enclosed in clinopyroxene oikocrysts in a subophitic style, swimming in a network of granular oxide norite (Figure S1 in the auxiliary material) [see also Teagle et al., 2006, Figure F210]. ${ }^{1}$ An overview of the petrographic characteristic of the investigated Hole $1256 \mathrm{D}$ gabbros is presented in Table 2.

\subsubsection{Principal Lithological/Textural Components}

[13] We identified three principal components making up the gabbros of Hole 1256D, which are closely associated in variable proportions in domains of different lithologies/textures (Figure 2):

[14] 1. Subophitic domains are composed of millimeter-sized poikilitic clinopyroxenes enclosing plagioclase chadacrysts, which generally show hollow shapes (i.e., skeletal morphology; Figure S2 in the auxiliary material) which suggest fast crystal growth. No other minerals are present.

[15] 2. Granular domains are mostly composed of prismatic plagioclase, amphibole, orthopyroxene, and granular oxide. Primary magmatic amphiboles characterized by idiomorphic crystal shape [e.g., Teagle et al., 2006, Figure AF3D] only rarely survived a secondary overprint where they were altered to hornblende or actinolitic aggregates. The characterization of these amphiboles as primary magmatic is based on the compositions and calculated equilibrium temperatures (see below). While clinopyroxene is often absent, relatively iron-rich olivine (forsterite content: 62-68) may join this assemblage. Rarely, quartz is present forming interstitial granophyric intergrowths with albitic plagioclase. Some apatites are also rarely observed.

[16] 3. Microgranular domains are composed of wormy intergrowth of plagioclase, clinopyroxene, orthopyroxene, oxide \pm amphibole, mostly as roundish inclusions within the granular gabbro. Average grain size is about $50 \mu \mathrm{m}$. Clinopyroxene grains bear numerous inclusions of micrometersized oxide spots, which is a characteristic feature observed in the granoblastic dikes [Teagle et al., 2006; Koepke et al., 2008; France et al., 2009b; Alt et al., 2010] and also in the residual minerals left after experimental partial melting of previously

\footnotetext{
${ }^{1}$ Auxiliary material data sets are available at $\mathrm{ftp} / / / \mathrm{ftp}$. agu.org/ apend/gc/2011 gc003655. Other auxiliary material files are in the HTML. doi:10.1029/2011GC003655.
} 
hydrothermally altered dikes [France et al., 2010]. A typical example of this domain is shown in Figure 2c.

\subsubsection{Intrasample Heterogeneity and Mixed Domains}

[17] In each thin section of all gabbros investigated in this study, at least two domains were identified (Table 2). Gabbro 1 contains typically associations of subophitic and granular domains and the amount
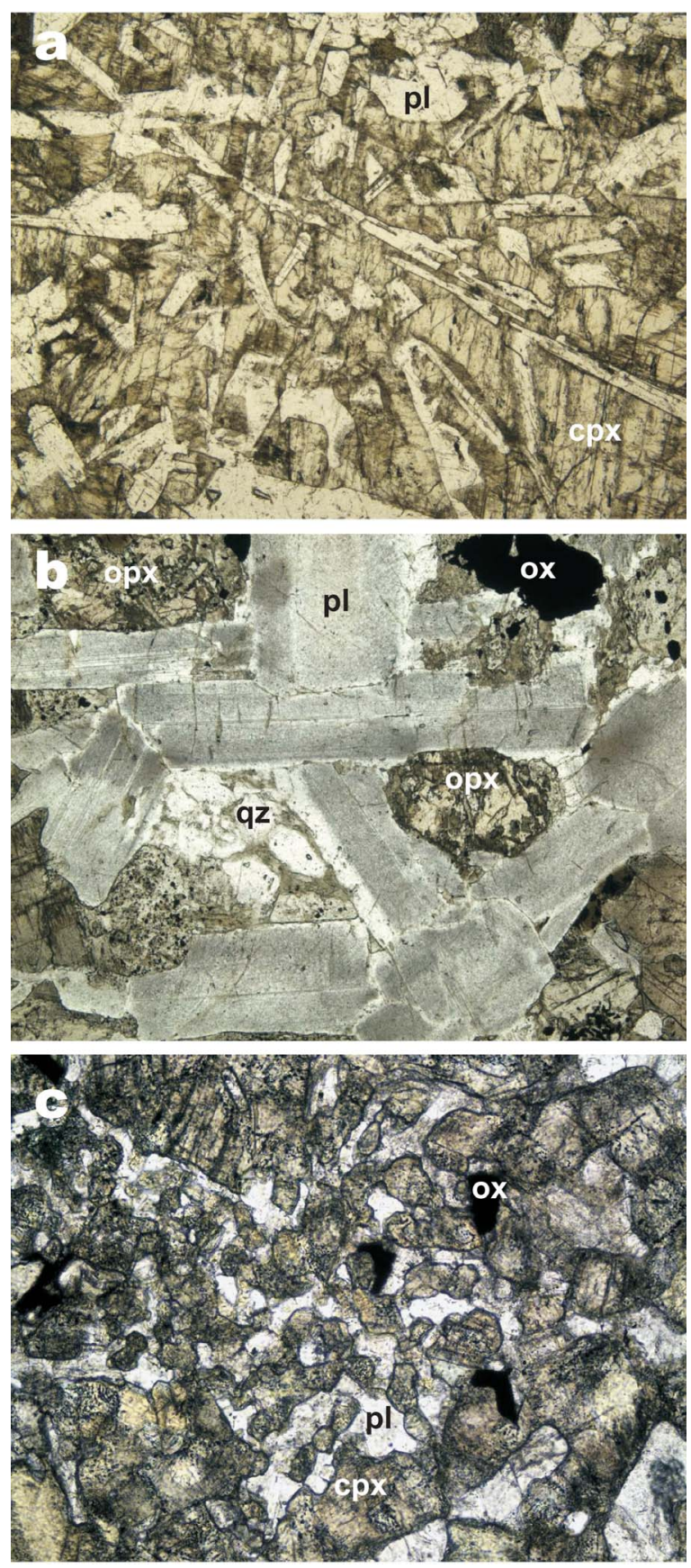

of microgranular domains is rare $(<1 \%)$. Toward the bottom of Gabbro 1 the subophitic domains become lesser and the granular domains dominate. A rough estimation of the proportions of subophitic and granular domains in the upper part of Gabbro 1 (e.g., core 14 and 15) was possible due to a careful macroscopical inspection of the core, which was performed by one of us (L.F.) during a postcruise visit at the IODP Gulf Coast Repository. The proportion of the whitish granular domain was estimated as representing up to $35 \%$ of the cores. In some samples, distinguishing these two domains is visually possible, since the subophitic domains with poikilitic clinopyroxene are darker than the granular domains, which are generally coarser grained, and often show up as whitish patches. The whitish color is due to a stronger alteration of the more albite-rich plagioclase, resulting in the characteristic patchy appearance of Gabbro 1 (see Figure S1 in the auxiliary material).

[18] The distribution of different domains can be rather complex as demonstrated in Figure 3 that shows sample 232_2_98_100 from Gabbro 2. This sample is composed of 4 different domains, but the transition between domains is usually gradual and

Figure 2. Microphotographs showing the principle textural/lithological domains occurring in Hole 1256D gabbros. For details see text and Table 2. All images with plane-polarized light. Images (plane-polarized light) are from the Janus Database related to Expedition 312 (http://www-odp.tamu.edu/database/). (a) Example of subophitic domain: medium grained gabbro showing millimeter-sized poikilitic clinopyroxene (cpx). Note that the enclosed plagioclase (pl) shows hollows and skeletal growth suggesting the record of fast crystal growth. These features are discussed in section 4.2.2. Sample 215_1_84_88; field of view $2.4 \mathrm{~mm}$. (b) Example of granular domain: medium grained oxide noritic domain showing a framework composed of prismatic plagioclase (pl), orthopyroxene (opx), and granular oxide (ox). This sample shows some peculiar features, which are not often visible in similar domains: the presence of interstitial quartz (qz) and slightly curved grain boundaries between the interlocking plagioclase crystals that is interpreted as typical cumulate features. Sample 232_2_98_100; field of view $2.4 \mathrm{~mm}$. (c) Example of microgranular domain: wormy intergrowth of plagioclase $(\mathrm{pl})$, clinopyroxene (cpx), and oxide (ox) as inclusion within a granular oxide gabbro. Note that the clinopyroxene grains bear numerous inclusions of micrometer-sized oxide spots. This feature and the overall textural appearance are well known from the granoblastic dikes, implying that these domains present relics of previously stoped granoblastic dikes. Sample 223_2_57_60; field of view $1.2 \mathrm{~mm}$. 
not sharp. Compared to Gabbro 1, Gabbro 2 shows a much lower proportion of subophitic domain, but significantly higher amounts of the microgranular domain. Quantifying the respective abundances in Gabbro 2 is very difficult, since they cannot be easily detected macroscopically as in Gabbro 1 . In general, the amount of the microgranular domain can be estimated as small, not exceeding $5 \%$, but it can locally reach $\sim 30 \%$ of the core.
[19] Petrographic investigation of the gabbros performed during IODP Expedition 312 emphasized the significance of metamorphic effects in Hole $1256 \mathrm{D}$ gabbros, not observed in other oceanic gabbros so far [Teagle et al., 2006]. In particular, these are (1) large orthopyroxene grains that contain micrometer-sized inclusions of granular clinopyroxene, (2) poikiloblastic intergrowths of orthopyroxene and clinopyroxene enclosing plagioclase matrix crystals, (3) concentration of orthopyroxene

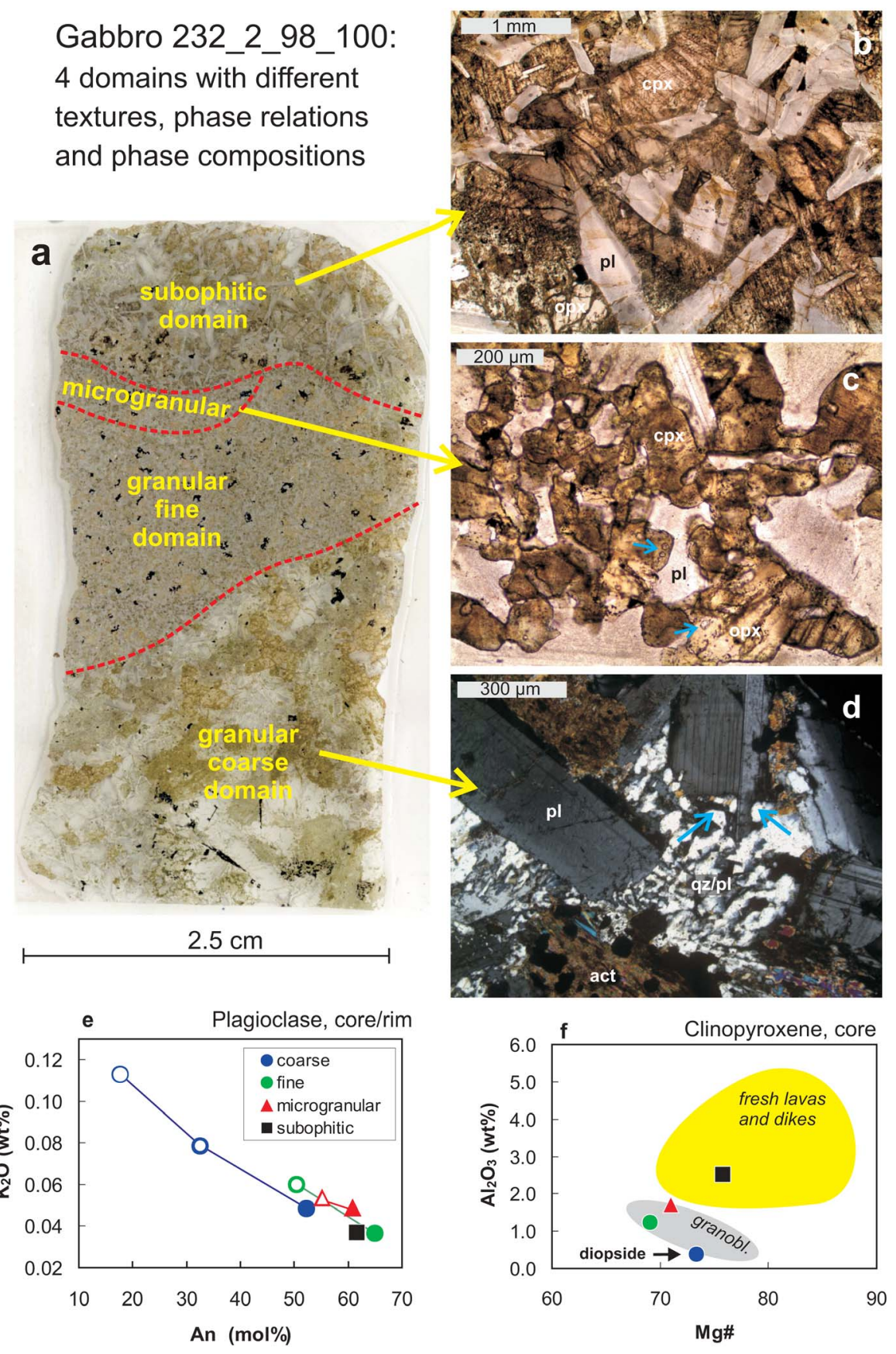

Figure 3 
along veins, and (4) the presence of microgranular patches with wormy intergrowth of pyroxenes and plagioclase interpreted as stoped fragments of granoblastic dikes [France et al., 2009b]. Many pyroxenes in the granular and microgranular domains, especially from Gabbro 2, contain numerous inclusions of micrometer-sized roundish minerals, which are not in optical continuity, with typical features well known from metamorphic rocks but not from oceanic gabbros. These minerals are mostly clinopyroxenes included in orthopyroxene (Figure S4 in the auxiliary material) [see also Teagle et al., 2006, Figure F241], and sometimes plagioclases included in orthopyroxene and clinopyroxene [Teagle et al., 2006, Figure F240]. Textural arguments, such as "classical" poikiloblastic structures, or the type of inclusions ("millions" of 1 to $20 \mu \mathrm{m}$ sized roundish grains) are not typical of simple poikilitic assemblages formed in a magmatic regime. Similar features are described by France [2009], compared with experimental products (results of melting of previously hydrothermally altered dikes from France et al. [2010]), analyzed by EBSD (electron backscatter diffraction) technique, and are attributed to assimilation of partly melted dikes or granoblastic dikes [France, 2009]. Some of the clinopyroxene inclusions show, in turn, $\mu \mathrm{m}$-sized inclusions of ilmenite. This is a key feature of the granoblastic assemblages [Teagle et al., 2006; Koepke et al., 2008; France et al., 2009b; Alt et al., 2010; France et al., 2010]. Another interesting feature is the local occurrence of Fe-Ti oxide [Teagle et al., 2006,
Figures F240 and F243] and even sulfide inclusions in prismatic orthopyroxene within the granular domain of Gabbro 2 (Figure S5 in the auxiliary material), a feature not described in oceanic gabbros so far. One possible explanation for this peculiar feature is that orthopyroxenes with sulfide inclusions could be inherited from stoped and partly assimilated granoblastic dike fragments. Sulfide inclusions within orthopyroxene are known in granoblastic dikes, and are interpreted as the metamorphic record of sulfide-bearing assemblages formed by hydrothermal alteration prior to the granoblastic overprint [Koepke et al., 2008]. Some plagioclase grains are highly heterogeneous, and display uncommon features such as sieve and sponge-like structures, as well as patchy zoning with anorthite enrichments in the rims of the crystals (Figure S6 in the auxiliary material). Complex relations are also observed in microgranular xenoliths hosted in gabbros; one characteristic example show reverse zoning in plagioclase, orthopyroxene rimming olivine grains, and several tiny oxides included in olivines and orthopyroxenes (Figure S6c in the auxiliary material). A general interpretation of all these features is presented below.

\subsection{Hydrothermal Alteration}

[20] All gabbroic rocks suffered a pervasive hydrothermal alteration mostly under greenschist facies condition, expressed by the presence of patches and veins mainly filled with chlorite, epidote, titanite, secondary amphibole (actinolitic to actinolitic

Figure 3. Sample 232298100 from Gabbro 2 illustrates the extreme patchiness in Hole 1256D gabbros. This sample shows four different lithological/textural domains within one thin section. For details see text. Figures $3 \mathrm{a}-3 \mathrm{c}$ with plane-polarized light. (a) Whole thin section image, with the different domains highlighted. The length of the thin section is $4.8 \mathrm{~cm}$. (b) Subophitic gabbronoritic domain ("subophitic" in Tables 1 and 2). Clinopyroxene (cpx) and one orthopyroxene (opx) oikocrysts with plagioclase (pl) laths as chadacrysts form subophitic domains. Note the dusty appearance of the plagioclase, which is a common feature for Gabbro 2. (c) Microgranular gabbronoritic domain ("microgranular" in Tables 1 and 2). Wormy intergrowths between granular orthopyroxene and clinopyroxene and plagioclase form a typical microgranular network, which is well known from the granoblastic dikes. Note the numerous inclusions of micrometer-sized oxides and silicates crystals in the pyroxenes, which are interpreted as inherited from a former granoblastic stage. Some inclusions in orthopyroxene could be identified as clinopyroxene (blue arrows) with the same composition as those from the microgranular network. We interpret this domain as a part of dike xenolith. (d) Granular noritic domain ("granular coarse" in Tables 1 and 2). Strongly zoned, tabular plagioclases form an interlocking network with granophyric intergrowth between quartz and plagioclase (qz/pl) in the interstices. Note that tabular plagioclases show corroded boundaries at the contact (blue arrows) implying reactions between the tabular plagioclase and the late quartz-saturated melt. Primary mafic minerals within the interstices are orthopyroxene and probably amphibole, now completely altered to a mix of actinolite/chlorite (act). (e) Compositional relations between the plagioclases in the different lithological domains including zoning effects within individual grains. "Coarse" and "fine" stand for "granular coarse" and "granular fine," respectively. Solid symbols indicate core compositions, and open symbols indicate rim compositions (for granular coarse domain, normal rim is indicated by open circle with thick line, and outermost rim is indicated by open circle with thin line). (f) Compositional relations between clinopyroxene cores in the different lithological domains. Included are the fields for fresh lava/dikes and for the granoblastic dikes of the extrusive section of Hole 1256D from Koepke et al. [2008]. Symbols as in Figure 3e. 
hornblende), secondary plagioclase (more Ab-rich than the primary), secondary magnetite, and very rarely potassium feldspar [Teagle et al., 2006; Alt et al., 2010]. Moreover, many gabbros show the record of a static hydrothermal overprint at higher temperatures under amphibolite facies condition, expressed by the presence of diopsidic pyroxene and hornblende that often forms pseudomorphs after idiomorphic magmatic amphibole, which is magnesiohastingsitic in composition (Table 3). Singleclinopyroxene thermometry using the thermometer of France et al. [2010] for secondary diopsides of three samples (Table 3) revealed equilibration temperatures between 714 and $761^{\circ} \mathrm{C}$ (Table 2), well within the amphibolite facies, matching also the observation of secondary orthoamphibole overgrowth in Gabbro 1 [Teagle et al., 2006]. The Ti-in-amphibole temperatures estimated for magnesiohornblendes vary between 601 and $761^{\circ} \mathrm{C}$ (Table 2). A detailed review of the subsurface structure of the submarine hydrothermal system in the drilled rocks of Site $1256 \mathrm{D}$ including the gabbro section is given by Alt et al. [2010].

\section{Mineral Compositions, Thermometry, and Magma Evolution}

\subsection{Major Element Compositions}

[21] The striking mineralogical and textural difference between the different domains composing Hole 1256D gabbros is also reflected by a significant contrast in phases chemistry. While the mineral compositions in the subophitic domains are in general more primitive, compositions in the granular domain are of more evolved character, as outlined in the following subsections.

\subsubsection{Subophitic Domains}

[22] Clinopyroxenes from subophitic domains display similar $\mathrm{TiO}_{2}$ and $\mathrm{Al}_{2} \mathrm{O}_{3}$ contents than those from fresh lavas and dikes (Figures $3 \mathrm{f}$ and $4 \mathrm{a}$ ). $\mathrm{Mg}$ \# varies between 74 and 85 , and are similar to the most primitive fresh lavas and dikes from upper section (Figure 4b). Plagioclase chadacrysts vary only slightly in An content, showing values within the range of fresh lava and dikes (Figure 4b). In the plagioclase An content versus clinopyroxene $\mathrm{Mg}$ \# diagram (Figure 4b), a crystallization path is included which was modeled with COMAGMAT [Ariskin, 1999] for fractional crystallization, by using as starting composition the sample representing the most primitive basalt composition of recovered lava and dikes (sample 1256D, 309, 161R, 2-1 cm, piece 9; composition given by Teagle et al. [2006]). Both the analyzed minerals of fresh lavas/dikes and plagioclase chadacrysts of the subophitic domain fit well with the modeled trend (except of three data points plotting to higher An values) suggesting that the subophitic lithologies and the extrusive rock correspond to the same evolution trend produced by fractional crystallization of a relative primitive MORB melt. Since most of the analyzed minerals of the subophitic domains plot near the starting point of the modeled trend, it can be assumed that the subophitic patches are related to crystallization of relatively primitive MORB melts.

[23] Both clinopyroxenes and plagioclases show typical normal zoning patterns toward the crystals rims, which is expressed (Table 3) by lower $\mathrm{Mg}$ \# and $\mathrm{Cr}_{2} \mathrm{O}_{3}$ contents (Figure $\mathrm{S} 2$ in the auxiliary material), and lower An contents (Figure S3 in the auxiliary material). This indicates melt evolution toward more fractionated compositions.

[24] Some clinopyroxene oikocrysts from the subophitic domains show a characteristic structure of wormy lamellae in the outer rims, in part with symplectitic quartz-plagioclase intergrowths at the contact to primary amphibole of the granular network domain. For details see Teagle et al. [2006, Figure AF3]. The composition of these zones is distinct from the clinopyroxene core compositions, with lower $\mathrm{Mg}$ \# and contents of $\mathrm{Ti}, \mathrm{Al}, \mathrm{Na}$ (Table 3). Striking is the low $\mathrm{Cr}_{2} \mathrm{O}_{3}$ content approaching zero, while the corresponding values of the core vary between 0.3 and $0.7 \mathrm{wt} \%$. These zones are also compositionally different from the "normal" zoned rims of the clinopyroxene oikocrysts, which have $\mathrm{Cr}_{2} \mathrm{O}_{3}$ contents between 0.2 and 0.6 wt \% (Figure $\mathrm{S} 2$ in the auxiliary material and Table 3 ). We interpret these zones as high-temperature reaction products between the just formed clinopyroxene oikocrysts and an evolved, hydrous melt crystallizing amphibole. Temperature estimations by using the single pyroxene geothermometer of France et al. [2010] reveal 50 to $100^{\circ} \mathrm{C}$ lower equilibrium temperatures for the wormy intergrowth compared to the core compositions of the same clinopyroxenes. These results should be considered with caution since the calibration experiments of this geothermometer have been performed in water-saturated conditions, while the exact water activities prevailed during the formation of the clinopyroxene cores and during the high-temperature reactions at the rim are not known. At least for the reaction process, high water activities could be assumed due to the pres- 
ence of coexisting amphibole [e.g., Johnson et al., 1994].

\subsubsection{Granular Domains}

[25] The principal phases of the granular domain display more heterogeneous compositions than minerals from the subophitic domains. Plagioclases are strongly zoned with core compositions similar
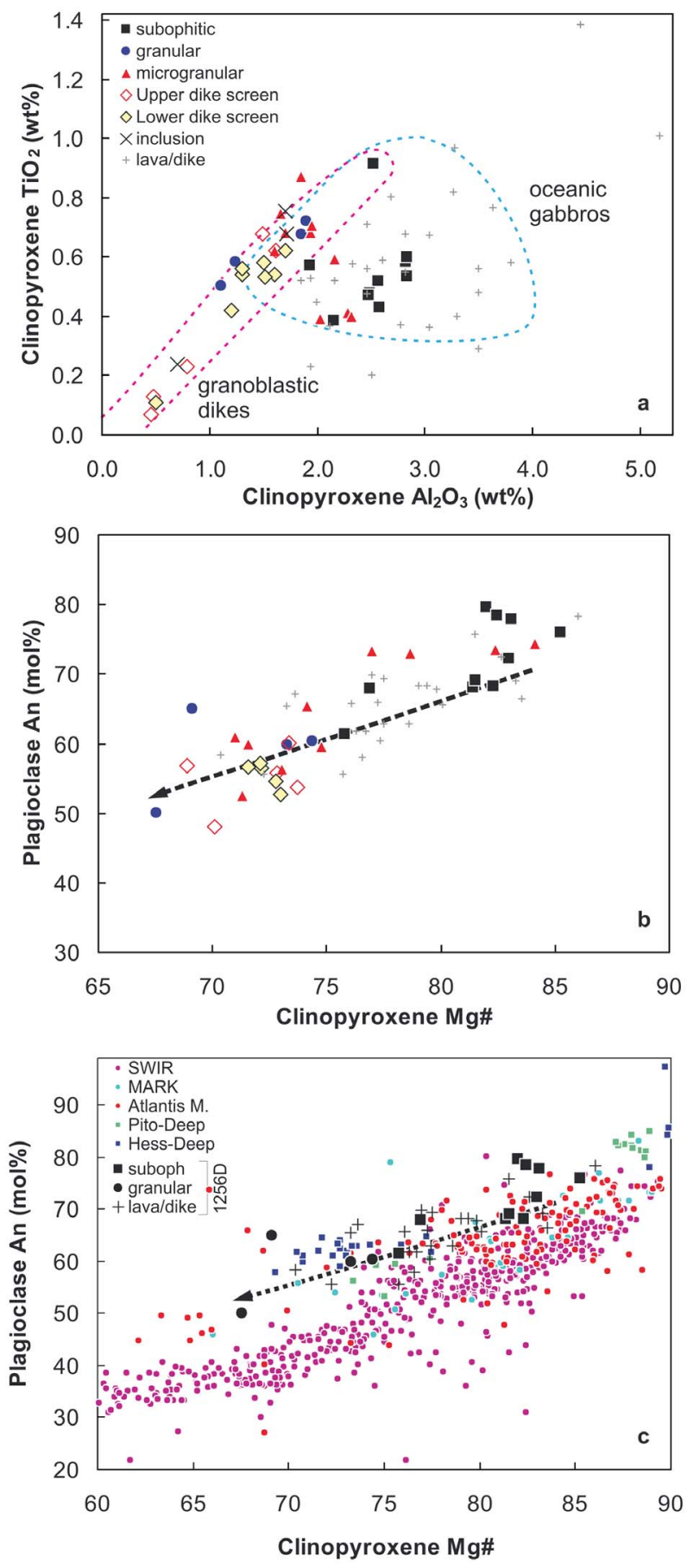

to the subophitic domain plagioclases (up to $\mathrm{An}_{80}$ ), and strongly evolved margin compositions, as low as $\mathrm{An}_{30}$ (Table 3). The complex zoning of plagioclases from granular domains can be observed within a single microprobe profile (Figure S3 in the auxiliary material). The high An contents in this profile are related to more or less euhedral "ghost" crystals, with compositions similar to subophitic domain plagioclases (Figure S3 in the auxiliary material). These are enclosed by plagioclase with significantly lower An content (Figure S3 in the auxiliary material). Relatively low $\mathrm{Mg}$ \# were obtained for coexisting orthopyroxene (63-75; Table 3). Low Mg \# are also typical for the coexisting olivines in this domain with values ranging between 65 and 74 (Table 3), thus not corresponding to the olivines with higher forsterite contents of typical primitive olivine gabbros.

[26] Few analyzed clinopyroxenes vary in their $\mathrm{Mg} \#$ from 68 to 74, highlighting more evolved composition than for the subophitic domains (Figure 4).

Figure 4. Composition of minerals from the gabbroic section of Hole 1256D. Data points correspond to averages presented in Table 3 (only compositions of the central parts of the grains). (a) $\mathrm{TiO}_{2}$ versus $\mathrm{Al}_{2} \mathrm{O}_{3}$ in the clinopyroxenes. Included are data points from fresh lavas and dikes from Leg 206 and Expedition 309 published by Dziony et al. [2008] and Yamazaki et al. [2009]. Data for the lower dike screen include analyses by Yamazaki et al. [2009]. The red field for the granoblastic trend is from France et al. [2009b]; the blue field for oceanic gabbro corresponds to data from various settings presented in Figure 4c. (b) Plagioclase An content versus clinopyroxene Mg \#. The modeled trend (dashed black line) was calculated with COMAGMAT [Ariskin, 1999] using a fractional crystallization model (up to $75 \%$ crystallization) and the most primitive bulk composition of recovered lava as starting composition. For details see text. For symbols see Figure 4a. (c) Plagioclase An content versus clinopyroxene $\mathrm{Mg}$ \# for subophitic and granular domains from 1256D gabbros and from gabbros from key locations for deep crustal rocks. Included are data for fresh lavas and dikes from Site 1256D from Dziony et al. [2008] and Yamazaki et al. [2009]. The modeling trend (dashed black line) was calculated with COMAGMAT (see Figure 4b). Data for oceanic gabbros are from the Southwest Indian Ridge (SWIR) [Dick et al., 2002], the Mid-Atlantic Ridge near the Kane fracture zone (MARK) [Coogan et al., 2000a, 2000b; Koepke et al., 2005a; Lissenberg and Dick, 2008], the Atlantis Massif at the Mid-Atlantic Ridge (Atlantis M.) [Suhr et al., 2008], the East Pacific Rise at Pito Deep [Perk et al., 2007], and the East Pacific Rise at Hess Deep [Dick and Natland, 1996; Miller et al., 1996; Natland and Dick, 1996; Coogan et al., 2002a]. 
Due to the rarity of clinopyroxene within the granular domains, only a few data points of clinopyroxene are included in the diagrams of Figure 4. It became clear after microanalyses that many clinopyroxenes observed in the granular domains during microscopic survey do not belong to the crystallization sequence of the principal magmatic phases of the granular stage. These were identified either as high-temperature metamorphic products (diopsidic, see above; Table 3), or as fragments of those poikilitic clinopyroxenes characteristic of the subophitic domains.

[27] Most data fit well the modeled evolution trend of Figure $4 b$, and plot at the fractionated end of the modeled compositions, compatible with $50 \%$ to $80 \%$ of crystallization (starting from the most primitive basaltic composition recovered), hence in agreement with the granular domain proportion estimated macroscopically ( $<35 \%$; see above). Temperature estimations using the single-clinopyroxene thermometer of France et al. [2010] for the subophitic and the granular domains also point toward a more evolved composition of the granular domains in comparison to the subophitic ones: while clinopyroxenes from subophitic domains reveal equilibrium temperatures ranging from 920 to $1010^{\circ} \mathrm{C}$, those from granular domains reveal lower temperatures ranging from 780 to $920^{\circ} \mathrm{C}$. However, due to the usage limitations of the thermometer of France et al. [2010] (high water activities in the experiments, and the relative low maximum calibration temperature of $1030^{\circ} \mathrm{C}$ ), and to the fast crystallization of clinopyroxenes from subophitic domains (see section 4.2.2), which may trigger an increase in $\mathrm{Al}$ content, these estimations should be considered with caution.

[28] Analyzed amphiboles (Table 3) in the granular domains vary in composition mostly between magnesiohornblende and magnesiohastingsite. The compositions of those amphibole with high $\mathrm{Al}$ contents on the tetrahedral position and high $\mathrm{Na}+\mathrm{K}$ contents on the A position in the formula (magnesiohastingsite), together with the observation that these amphibole show relictic euhedral prismatic habit, support the interpretation of the petrographic observation that these amphiboles are indeed primary magmatic products. Amphibole thermometry reveals maximum equilibrium temperatures of $925^{\circ} \mathrm{C}$ (hornblende-plagioclase) and $1009^{\circ} \mathrm{C}$ (Ti-in-amphibole; for details see Table 2), which are consistent with a primary magmatic origin according to experimental constraints [e.g., Ernst and Liu, 1998]. For details about the amphibole thermometer see section 1.2.
[29] Some plagioclases (Figure S6 in the auxiliary material) are characterized by complex zonations with albite-rich zones surrounded by anorthite rich rims. These features are discussed in section 4.3.2.

\subsubsection{Microgranular Domains and Inclusions}

[30] Clinopyroxenes and plagioclases from the microgranular domains display highly heterogeneous compositions, ranging from relatively primitive compositions (similarly to subophitic domains) to more evolved (similarly to granular domains; Figures $4 \mathrm{a}$ and $4 \mathrm{~b}$ ). Compositions also roughly reproduce the COMAGMAT model evolution trend (see section 3.1.1). Microgranular inclusions of clinopyroxenes observed within orthopyroxenes form granular domains (see section 2.1.3) and follow the general trend of granoblastic dikes in the $\mathrm{TiO}_{2}$ versus $\mathrm{Al}_{2} \mathrm{O}_{3}$ diagram (Figure 4). Some of the investigated microgranular xenoliths also show atypical reverse zoning from $\mathrm{An}_{58}$ in mineral cores to $\mathrm{An}_{75}$ in rims and along cracks (Figure S6c in the auxiliary material).

\subsubsection{Comparison With Oceanic Gabbros}

[31] For comparison with oceanic gabbros from other locations, only data points of the subophitic and the granular domains are considered. In Figure 4c, the plagioclase An content versus clinopyroxene $\mathrm{Mg} \#$ is plotted, including the differentiation trend modeled with COMAGMAT (see section 3.1.1.). Mineral compositions from Hole 1256D gabbros are relatively similar to those of other samples from the fast spreading EPR (Hess Deep and Pito Deep), and plagioclases are enriched in An content with respect to those from slow spreading ridges, which follow a trend with a generally lower $\mathrm{Ca} / \mathrm{Na}$ ratio. This difference between fast and slow spreading ridges was shown by Coogan [2007], who modeled the magma evolution from slow spreading systems by using a starting composition with a lower $\mathrm{Ca} / \mathrm{Na}$ ratio compared to that used in this study. It should be noted that the gabbros from Hole 1256D correspond to the highest level in the plutonic oceanic crust, while the trends shown for other localities correspond to deeper levels in the plutonic crust.

\subsection{Trace Element Concentrations}

\subsubsection{Mineral Compositions}

[32] Mineral (clinopyroxene, orthopyroxene, and plagioclase) trace element contents have been analyzed in one dike sample, and in gabbros (average 
values are presented in Table 4, and the full database is available as Table $\mathrm{S} 1$ in the auxiliary material). In gabbro samples, both subophitic (clinopyroxene and plagioclase) and granular (orthopyroxene and plagioclase) domains have been investigated; clinopyroxene from granular domains were too small to be analyzed. Chondrite normalized clinopyroxene Rare Earth Elements (REE) patterns from subophitic domains are depleted in light REE (LREE), display a small $\mathrm{Eu}$ negative anomaly, and a relatively flat evolution from medium REE (MREE) to heavy REE (HREE; Figure 5). Normalized concentrations vary from 0.5 to 20 times the chondrite value (Figure 5). Intrasample variability is relatively small in all samples. Sample 232_2_98_100 is the one with the highest mineral REE concentrations. In orthopyroxene from granular domains chondrite normalized concentrations increase from the LREE to the HREE, and display a small Eu negative anomaly (Figure 5). Values range from 0.6 to 15 times the chondrite value. REE normalized plagioclase contents generally decrease from the LREE to the HREE, and display a marked Eu positive anomaly (Figure 5). Highest normalized concentrations are observed for La in granular domains ( 8 times the chondrite value), and the lowest HREE concentrations are 0.1 times the chondrite value. Plagioclases from granular domains display a higher variability and can reach higher concentrations for all REE than plagioclase from subophitic domains (Figure 5). This last observation is in agreement with the major element composition of plagioclase, that is more variable, and generally more evolved in the granular domains than in the subophitic domain (e.g., Figure S3 in the auxiliary material).

\subsubsection{Equilibrium Melts}

[33] To discuss the magmatic processes in the upper melt lens of fast spreading ridges, we calculated the REE composition of melts in equilibrium with clinopyroxene (hereafter MeltCpx-SO) and plagioclase (hereafter MeltPl-SO) in subophitic domains, and with orthopyroxene (hereafter MeltOpx-G) and plagioclase (hereafter MeltPl-G) in granular domains. Melt compositions are calculated by using partition coefficients presented in Table S2 in the auxiliary material [Wood and Blundy, 1997; AignerTorres et al., 2007; Van Kan Parker et al., 2010; Laubier et al., 2010; M. Laubier et al., personal communication, 2010]. We normalized the calculated melt compositions to Hole 1256D upper crust composition, that we assume to be equal to the average REE concentration of the basalts and dikes analyzed by Yamazaki et al. [2009], but excluding analyses from the granoblastic dikes that may have been modified during the reheating stage (composition presented in Table S1 in the auxiliary material).

[34] We also analyzed clinopyroxenes and plagioclases of one dike in order to assess the validity of our approach. The model melts in equilibrium with clinopyroxene and plagioclase in the analyzed dike, MeltPl-dike and MeltCpx-dike, both normalized to the average Hole 1256D upper crust as explained above, are thus expected to display a normalized value of one for all the REE. However, a slight LREE depletion and slight HREE enrichment is observed (Figure 6a). One possibility to explain this could be by fast mineral growth as suggested by the textural features of the phenocrysts (Figure $2 \mathrm{a}$ and Figure S2 in the auxiliary material). In the case of fast crystallization, LREE may be enriched compared to HREE within the melt boundary layer present at the crystal margin; $\mathrm{D}_{\text {LREE }}$ would thus be higher than $\mathrm{D}_{\text {HREE }}$ [e.g., Kennedy et al., 1993]. Nevertheless, it is known that LREE diffuse faster in silicate melts than HREE [e.g., Koepke and Behrens, 2001], the boundary layer will therefore be faster reequilibrated with the surrounding melt for LREE than for HREE. In the present case, the depletion in LREE relative to the HREE in Figure 6a suggests that this diffusion process is more effective than the LREE enrichment associated to the fast growth.

[35] Concentrations normalized to the 1256D upper crust for the MeltPl-SO, and the MeltCpx-SO are very similar to the melts calculated from the dike clinopyroxene and plagioclase (Figure 6b). These are slightly depleted in LREE in comparison to the HREE. MeltPI-G are highly variable, overlapping MeltPl-SO, and reaching values as high as 10 times the Hole 1256D upper crust (Figure 6c). MeltOpx-G display concentrations varying from $\sim 2$ to nearly 6 times the Hole 1256D upper crust (Figure 6c). REE concentrations of the calculated equilibrium melts normalized to the average $1256 \mathrm{D}$ extrusive crust are therefore in agreement with the on major and minor element mineral compositions (section 3.1), and point to melts with different compositions crystallizing the subophitic and the granular domains. While the melt crystallizing the subophitic domains can be regarded as equivalent to those relatively primitive melts feeding the upper crust (similar compositions for calculated melt in dikes and subophitic domains; Figures 6a and 6b), the melts related to the granular domains can be regarded as much more evolved. 


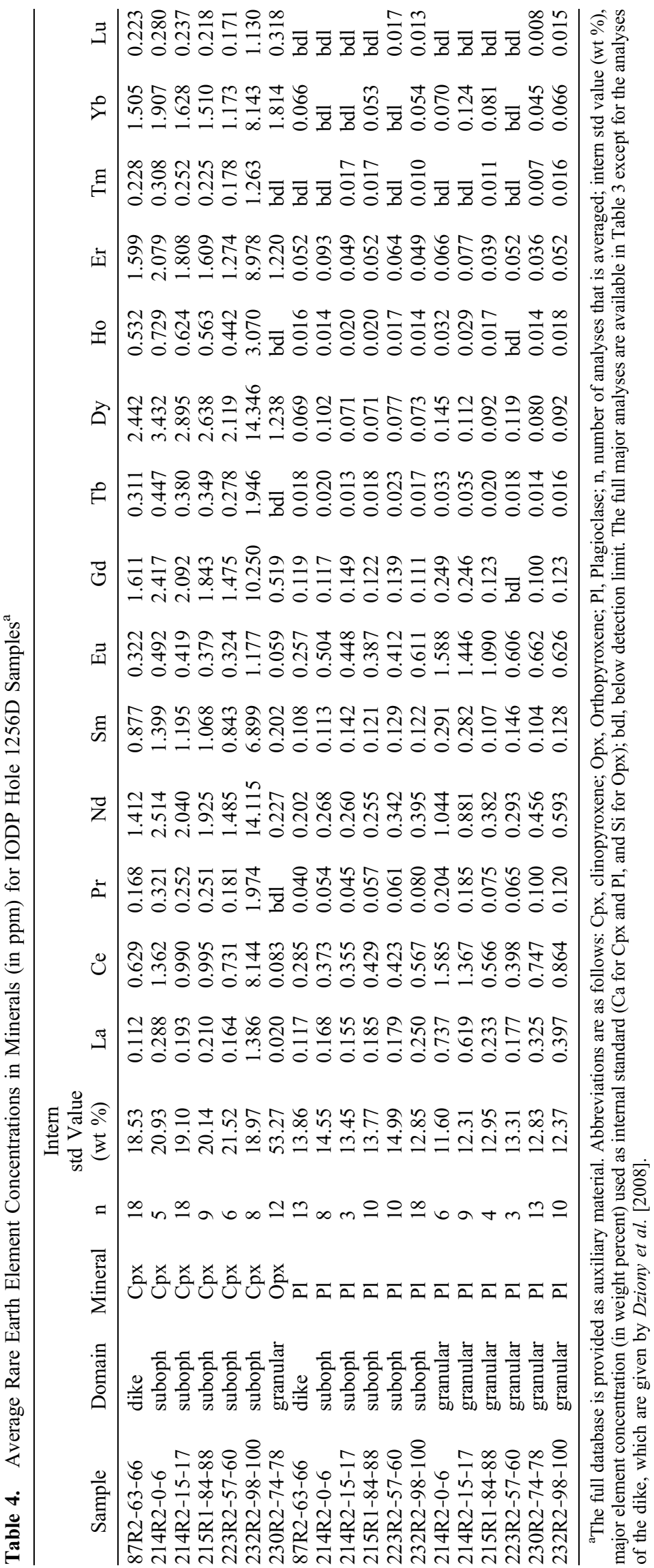




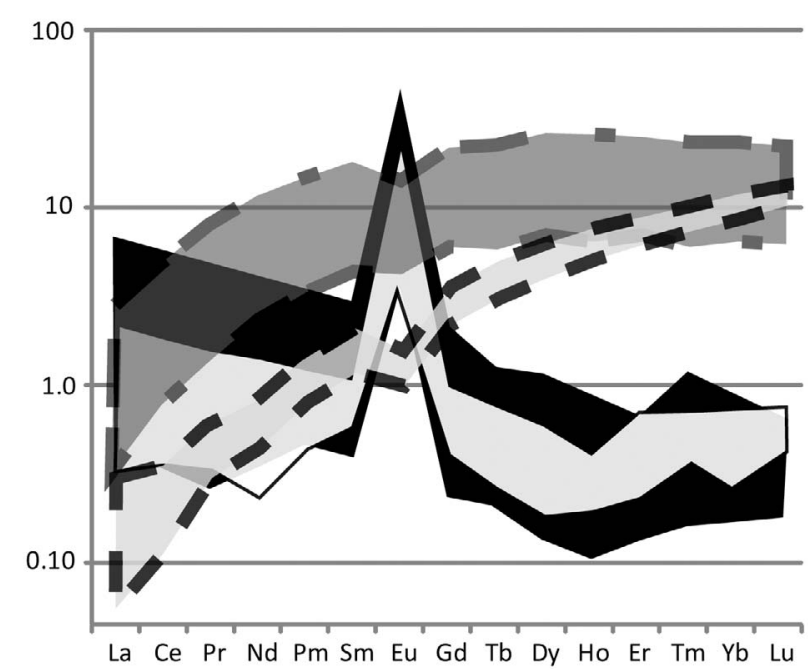

Figure 5. Chondrite normalized REE mineral concentrations (normalization values after Anders and Grevesse [1989]). Black field, plagioclase from granular domains; white field, plagioclases from subophitic domains; light gray field, orthopyroxene from granular domains; dark gray field, clinopyroxene from subophitic domains.

[36] The melt compositions calculated using clinopyroxenes from the complex, multidomain sample 232_2_98_100 are more evolved than those calculated for other samples (Figure 6d). The analyzed clinopyroxenes are part of a subophitic domain from Gabbro 2 which is texturally and compositionally different compared to the subophitic domains from Gabbro 1. This sample is characterized by an extreme patchiness showing 4 different lithological/textural domains within one thin section as illustrated in Figure 3. This feature is discussed in section 4.3.2.

\section{Discussion: Magmatic Processes at Fast Spreading Ridges}

\subsection{The Axial Melt Lens Feeds the Upper Crust}

[37] In the previous sections we showed that the compositions of the melts that crystallized subophitic and granular gabbro domains are significantly different (Figures 4 and 6). As documented by major and trace elements, subophitic domains crystallized from melts that are similar to those that fed the upper oceanic crust (Figures 3f, 4a, 4b, 6a, and $6 \mathrm{~b}$ ). This suggests a common source, which is very probably the axial melt lens at the base of the upper crust (Figure 7) [e.g., Sinton and Detrick,
1992; Singh et al., 1998, 1999; Canales et al., 2009]. Our results therefore imply that the upper crust is fed by the axial melt lens which is generally characterized by a low crystal fraction [e.g., Batiza and Niu, 1992]. Our new results are also in agreement with observations from the Oman ophiolite, where upper, isotropic, varitextured gabbros sampled at the sheeted dike complex base are interpreted to represent the fossilized melt lens [e.g., MacLeod and Yaouancq, 2000; France et al., 2009b], and where the subophitic domains correspond to the first crystallization product in that fossilization process. The local occurrence of highly evolved melts, too dense to erupt, within the melt lens have nevertheless been described at the East Pacific Rise [Natland and Dick, 1996], and in the Oman ophiolite [MacLeod and Yaouancq, 2000] and seems to challenge our observations. We discuss this point in the following section in details.

\subsection{Melt Lens Fossilization and the Complex Origin of Upper Isotropic Gabbros}

\subsubsection{Origin of the Different Gabbroic Domains: A Crystallization Sequence}

[38] The different observations (petrological, textural, major and trace element compositions) presented here allow us to propose a model for the evolution of the melt lens fossilization that results in the crystallization of the upper isotropic gabbros. Several observations shed light on the mechanism of the fossilization process itself: (1) Both major and trace elements mineral concentrations show that the granular domains crystallized from more evolved liquids than the subophitic domains (Figures 3, 6b, and 6c). (2) The textural transition between the subophitic and the granular domains is never sharp but continuous. (3) Relics of plagioclases and poikilitic clinopyroxenes derived from the subophitic domains are present in the granular domains (see section 3.1), implying that the magma crystallizing the granular domains is related to a relatively late interstitial stage. (4) Plagioclases from the granular domains are chemically highly variable, with compositions ranging from similar to those of the subophitic domain to more evolved (Figures 3, 6a, and $6 \mathrm{~b}$ and Figure $\mathrm{S} 3$ in the auxiliary material), recording a continuous evolution. (5) Temperature estimations based on the $\mathrm{Al}$ content of clinopyroxene [France et al., 2010] (Table 2) suggest that the subophitic domains crystallized generally at higher temperatures (always above $900^{\circ} \mathrm{C}$ ) compared to the granular domains (always below $900^{\circ} \mathrm{C}$ ). 

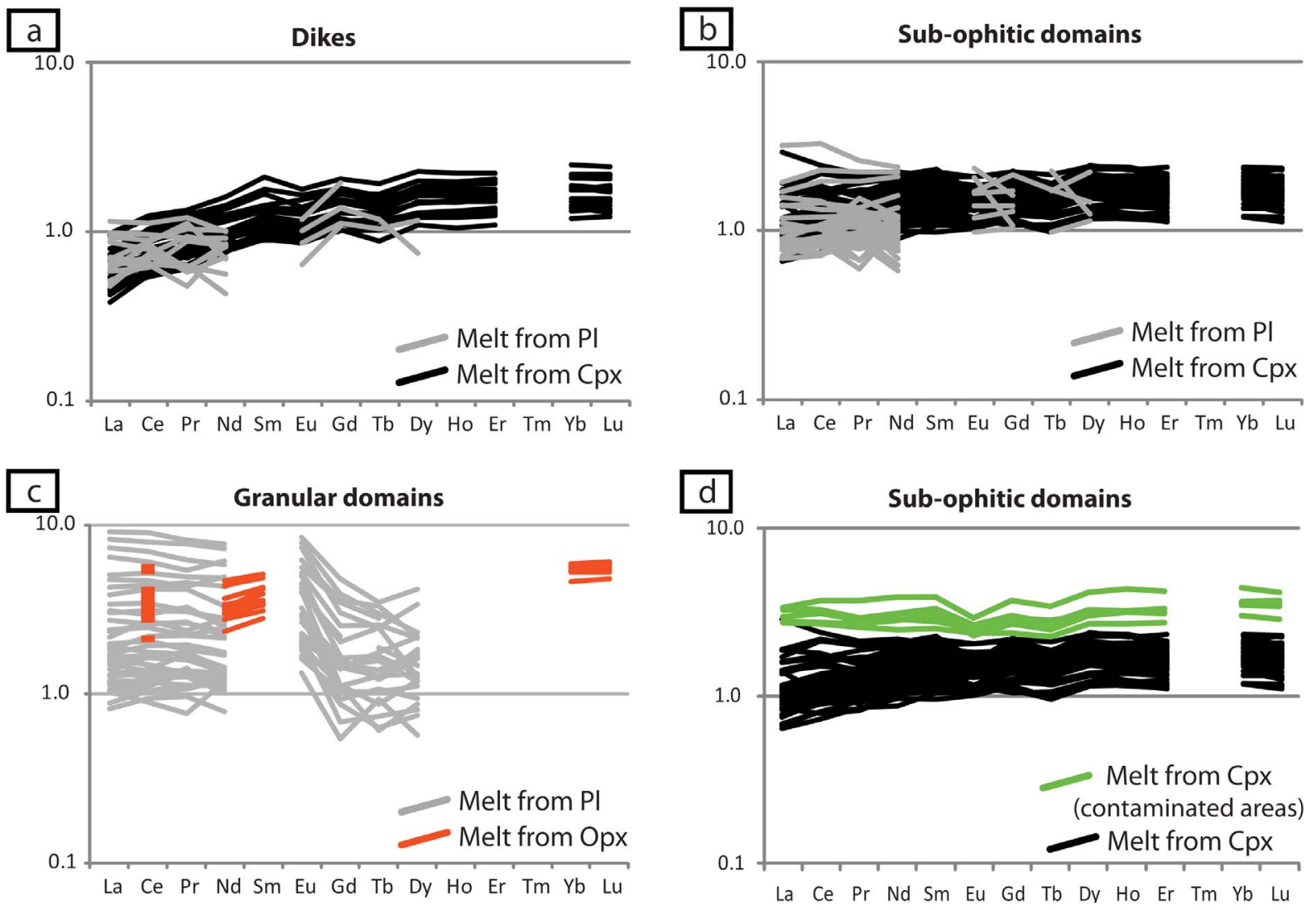

Figure 6. Calculated equilibrium melt compositions normalized to the assumed IODP Hole 1256D upper crust composition (averaged from Yamazaki et al. [2009]; see text for details). (a) Example of a fresh basalt from the sheeted dike section. Sample 309-1256D-87R-2, 63-66. Mineral analyses are published by Dziony et al. [2008]. (b) Subophitic domains (samples 214_2_0_6, 214_2_15_17, 215_1_84_88, 223_2_57_60, and 232_2_98_100). (c) Granular

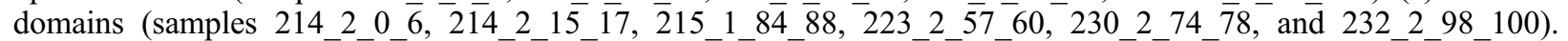
(d) Subophitic domain in the complex contaminated sample 232 2_ $\overline{98}-\overline{1} 100$ compared to other investigated subophitic domains.

[39] Taken together, all these observations allow us to characterize the melt lens fossilization process. The combined observations point to a common origin for both subophitic and granular domains which are regarded as a result of in situ fractionation following a crystallization sequence as depicted in Figure 8. MORB type melts that fill the melt lens and feed the upper crust start to crystallize clinopyroxene and plagioclase in a mushy zone, probably close to the melt lens margins, where decreasing temperatures allow the beginning of crystallization of the subophitic domains. The degree of crystallization increases when moving through the melt lens margin (i.e., toward cooler areas), and the subophitic domains start to build a relatively well connected framework trapping the remaining, more evolved melt (Figure 8). During the crystallization of the subophitic framework, the remaining trapped melt progressively evolves, with the potential to crystallize at lower temperature, leading to the noritic granular assemblages (Figure 8). This crystallization sequence is strongly supported by experimental studies in MORB-type system that showed the late crystallization (i.e., at lower temperatures) of orthopyroxene at the expense of clinopyroxene [e.g., Berndt et al., 2005; Feig et al., 2006, 2010]. Trace element modeling for fractional crystallization using partition coefficients presented in Table S2 in the auxiliary material shows that a melt composition similar to MeltOpx-G can be obtained by crystallizing $80 \%(50 \%$ of $\mathrm{Pl}$, and $30 \%$ of Cpx) of a melt similar to MeltCpx-SO. This model is also consistent with the major element mineral evolution, as demonstrated in the diagram on the cocrystallization of plagioclase and clinopyroxene (Figure 4; see section 3.1), and with the abundance of granular domains (always $<35 \%$ of the whole rock, see section 2.1.3). 


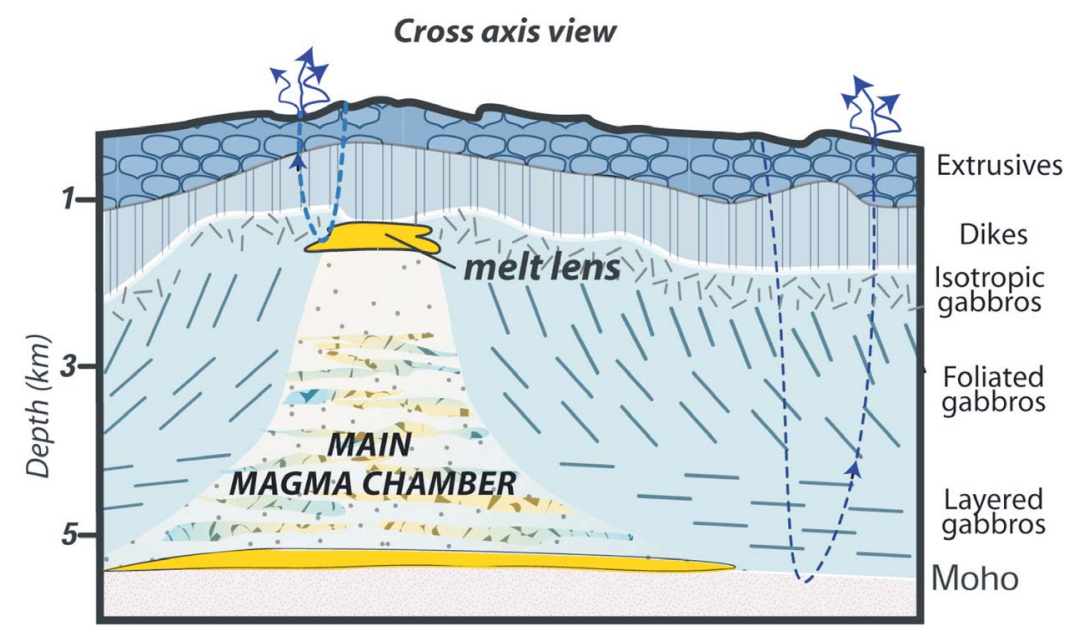

Figure 7. Schematic cross section of the magmatic system at fast spreading ridges (modified after France et al. [2009b]). The main magma chamber is composed of a mush containing less than $20 \%$ of melt, and the upper melt lens is nearly $100 \%$ liquid. The yellow lens at the bottom corresponds to sill-like intrusions [e.g., Boudier et al., 1996]. The dashed blue curves stand for possible hydrothermal cooling paths. The dark blue lines in the bottom part correspond to the layering in the gabbros.

[40] This model of in situ fractionation is independent of the structural interpretation of the drilled record of the gabbro/dike transition at Site 1256 as discussed in section 1.1. A prerequisite for our model is a thermal regime that allows cooling of the axial melt lens, which could be established for the general case at the melt lens margin as shown in Figure 8 (building on the structural model depicted in Figure 1b), or alternatively, within decameter thick intrusive apophyses fed from the melt lens (structural model depicted in Figure 1a).

\subsubsection{Why Do Subophitic Domains Grow Fast?}

[41] The subophitic texture of gabbros in Gabbro 1 is characterized by plagioclase chadacrysts displaying skeletal morphology, which are characteristic of rapid growth (Figure 2a and Figure S2 in the auxiliary material). Rapid growth shape is generally associated with fast cooling rates, in agreement with dynamic crystallization experiments that produced polyhedral, skeletal, and dendritic shapes by increasing the cooling rate [Donaldson, 1976;
Lofgren, 1980]. However, dynamic crystallization experiments show mainly that fast evolution of morphology results in deviation from equilibrium conditions [Lofgren, 1980; Faure et al., 2003]. This deviation can be represented by the degree of undercooling (i.e., temperature difference between liquidus temperature and real temperature of the liquid). There are several ways to obtain a large degree of undercooling: (1) rapid cooling rate, (2) thermal gradient, and (3) delay of nucleation. In the following, each process is discussed separately.

[42] 1. In oceanic crust settings, fast cooling rates are well documented in the basalts and dikes forming the upper crust, where a significant cooling rate is indicated due to the efficiently hydrothermally cooled environment. At ODP Site 1256D, skeletal or dendritic shapes are indeed well known from the extrusives of the upper section [e.g., Teagle et al., 2006, Figures F222 and AF1]. Moreover rapid growth textures are generally associated with large fraction of glass in pillow lavas and chilled margins in dykes [Teagle et al., 2006]. However, no glass or

Figure 8. Schematic model describing the upper part of the magmatic system present at IODP Hole 1256D. (a) Melt lens position at the base of the sheeted dike complex. The upper melt lens feeds the upper crust (dikes and lavas) and is fed from below. Small white dots at the melt lens margins highlight the mushy zone where the melt lens passes from $\sim 100 \%$ of melt to a fully crystallized gabbro. The black square represents the zoomed area represented in Figure $8 \mathrm{~b}$. The white area within the sheeted dike complex highlights a cut in the thickness. (b) Details of the mushy zone present at the melt lens margins. The crystallization progression is highlighted: first, the subophitic domains crystallize from MORB-like melts (yellow) forming a framework that traps the remaining evolved melt, and second, the Opx-bearing granular domains crystallize from these trapped fractionated melts (blue). (c) Corresponding REE patterns for calculated equilibrium melts based on clinopyroxene from the subophitic domains (yellow) and orthopyroxene from the granular domains (blue; normalized to the 1256D site upper crust composition) (for details see Figure 6). 
chilled margin has been observed in the studied gabbro, suggesting that the cooling rate was not efficient enough. Furthermore no textural variation is observed within the gabbro body when moving away from the dike/gabbro transition to the gabbro body center; such a variation should be present if the melt was rapidly cooled when meeting the dikes that are efficiently cooled by the hydrothermal system.
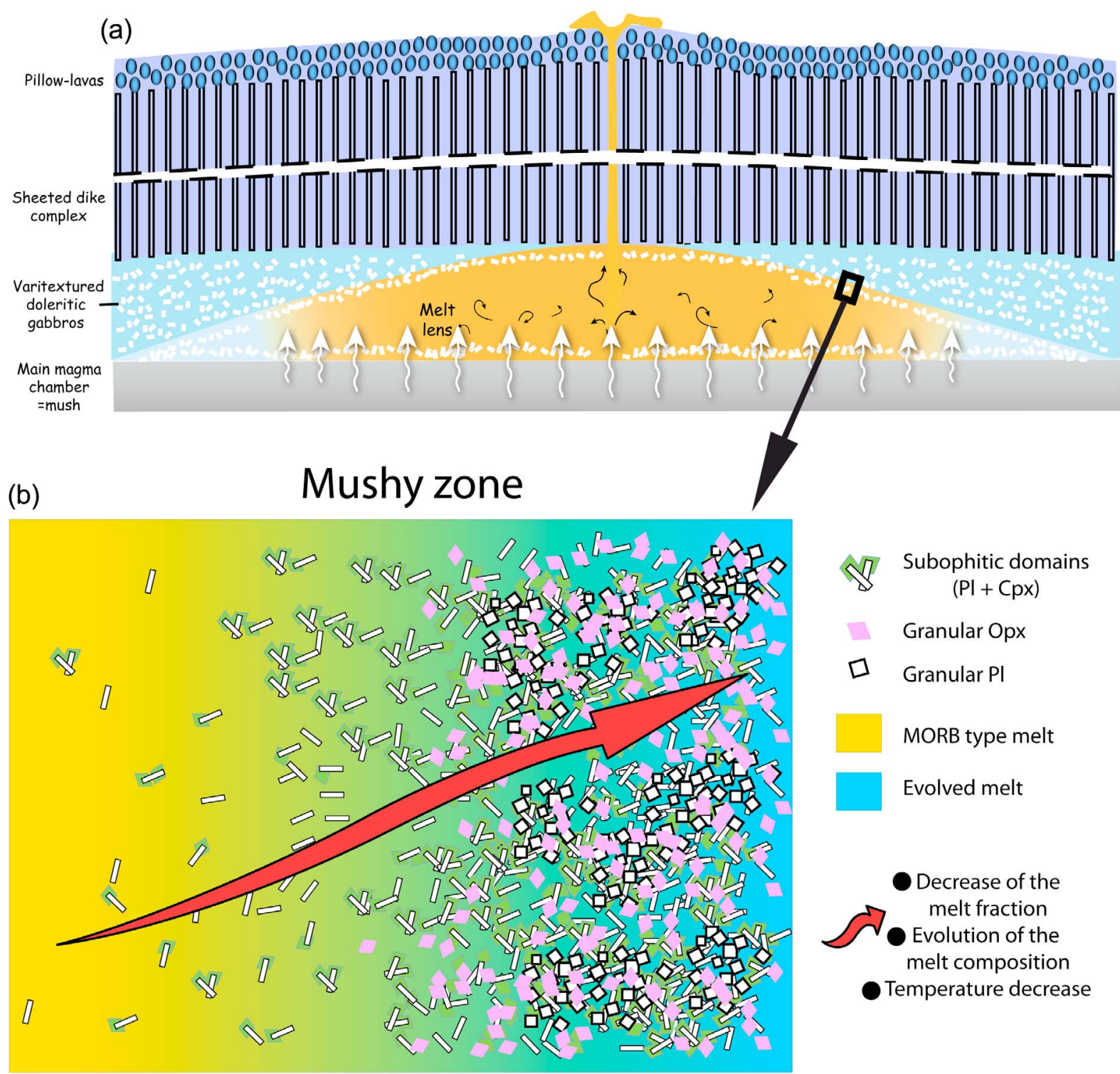

(17 Subophitic domains

$(\mathrm{PI}+\mathrm{Cpx})$

Granular Opx

G Granular PI

MORB type melt

Evolved melt

Decrease of the

$\sqrt{\text { Evolution of the }} \begin{gathered}\text { melt fraction } \\ \text { Evolution }\end{gathered}$ melt composition

Temperature decrease

(c)

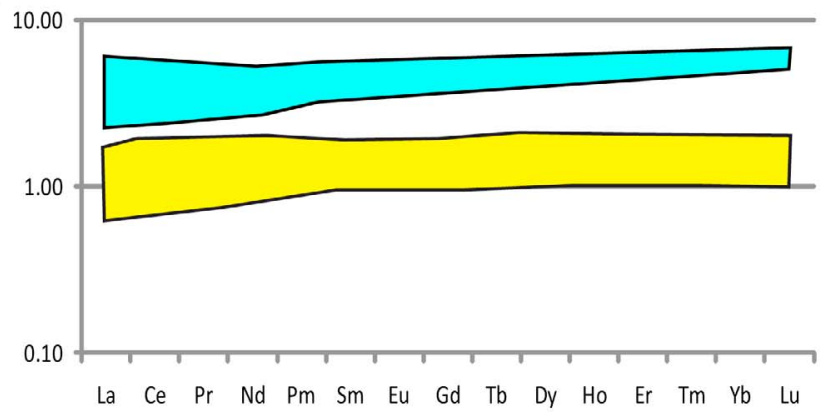

Figure 8 
[43] 2. It can be expected that a significant thermal gradient is a natural consequence of the presence of hot magmatic liquids in a cold oceanic crust environment. Thus, a strong thermal boundary layer must exist at the magma chamber interface. Experiments performed with thermal gradients show that crystals grow parallel to the gradient and develop a harrisitic texture [Donaldson, 1977], and field observations show that plagioclase crystals are able to develop this columnar dendrite morphology oriented perpendicular to the border of intrusions [Petersen, 1985]. In the gabbros studied here, skeletal plagioclase chadacrysts do not show any preferential orientation within clinopyroxene oikocrysts, even in the gabbro samples located at the contact with the dikes. The thermal gradient seems thus to be not affecting the crystallization style of plagioclase. Dynamic crystallization experiments have shown that thermal gradient can be without effect on crystallization when the cooling rate is fast or when nucleation of crystals is hampered [Faure et al., 2006]. As we have just shown that the cooling rate cannot be very fast in the present case, an alternative is to consider convection cells in the thermal gradient. If crystals move with liquid from the hot area to a cooler zone, then the result is similar to a fast cooling rate. Such crystal migration is well known in magma chambers, but generally crystals display oscillation between cold and hot zones that are recorded in crystal morphology or by large composition variation [Kuo and Kirkpatrick, 1982; Faure and Schiano, 2004; Welsch et al., 2009]. Plagioclase chadacrysts from IODP Hole $1256 \mathrm{D}$ gabbros do not show any of these textural and chemical features and are therefore hardly reconcilable with a convective mechanism.

[44] 3. Delay in nucleation could be the most probable mechanism to produce undercooling, and explain the rapid growth shape of plagioclases. Indeed, plagioclase is well known to display strong nucleation reluctance [Lofgren, 1976]. Similarly, nucleation of clinopyroxene could be delayed, inducing supersaturation that produces rapid growth of this mineral as soon as nucleation starts. Clinopyroxene crystals grow faster than plagioclase and engulf them as chadacrysts as proposed by Tegner and Wilson [1995].

[45] In summary, no large variations of cooling rates are necessary to explain the various morphologies observed side by side in the gabbros. Moreover, experimental studies on MORB-like melts crystallization shown that orthopyroxene starts to crystallized $80-100^{\circ} \mathrm{C}$ lower than plagioclase and clinopyroxene [e.g., Feig et al., 2006]. The $20 \%$ of melt trapped within the subophitic framework will therefore crystallize as soon as orthopyroxene saturation is attained to form the evolved granular domains. These textural considerations suggest that subophitic domains are a natural consequence of a delay of nucleation, and do not require fast cooling. This is also consistent with the observations that fast crystal growth is not restricted to the contact zones of Gabbro 1 at the dike/gabbro boundary, where hydrothermal cooling would be responsible for large thermal gradients, but also extend continuously into the inner parts of Gabbro 1. Therefore gabbros crystallize continuously either at the margins of the axial melt lens (Figure 1b) or in decameter thick sills interpreted as apophyses fed from the melt lens (Figure 1a).

\subsubsection{Isotropic Gabbros at Fast Spreading Ridges Are Composite Igneous Rocks}

[46] Our model on the formation of typical spotty and patchy gabbros during melt lens fossilization as discussed in section 4.2.1 allows us to reconcile petrological and geochemical features, and is supported by experimental studies. It highlights how the upper melt lens can both crystallize highly viscous, and dense fractionated melts (the granular domains [Natland and Dick, 1996; MacLeod and Yaouancq, 2000]), and feed the upper crust with MORB-type melts. The key is the complex fossilization/crystallization processes ongoing at the margins of the axial melt lens within a thin mushy zone (Figure 8). Our observations and microanalytical results reveal that the bulk rock composition of a given gabbro sample in the studied gabbroic section is governed by the presence and amount of different domains, which should not be ignored when applying bulk rock chemical approaches to the oceanic gabbros. Studying one of these gabbro samples as a single entity will systematically introduce a bias in the chemical balance of the system. As an example, whole rock REE compositions would point to a slightly cumulative origin in most cases, when plagioclase-rich subophitic domains are dominating the analyzed sample (Eu positive anomaly). In contrast, a more fractionated origin will be given by the bulk chemistry of a sample with a higher proportion of granular domains (higher REE contents; Eu negative anomaly). This bias is illustrated in Figure F8 of Neo et al. [2009] that shows bulk rock analyses from Gabbro 1 ("upper gabbro" in Figure F8 of Neo et al. [2009]) from the 1256D gabbros. The model proposed herein is consistent with the strong variability in REE concentrations recorded in the upper isotropic gabbros from IODP Hole 1256D [Neo et al., 
2009; Yamazaki et al., 2009] and from the Oman ophiolite [e.g., Coogan et al., 2002b].

\subsection{Evidence for Assimilation, Hydrous Partial Melting, and Melt Lens Contamination}

\subsubsection{Upper Melt Lens-Sheeted Dike Interactions: Assimilation}

[47] Beside the crystallization/fossilization model presented here, the different gabbro samples display assimilation features, which are microgranulargranoblastic xenoliths and patches mainly composed of two pyroxenes, plagioclase, oxides \pm amphibole, often with a general wormy appearance (Figures 2 and 3 and Figure S6 in the auxiliary material). A common characteristic is the occurrence of $\mu \mathrm{m}$-sized roundish clinopyroxenes included within larger orthopyroxenes from granular domains (Figure S4 in the auxiliary material). These characteristic lithologies are not so common in the upper part of gabbros (Gabbro 1), and more concentrated lower in the section. Based on field observations in the Oman ophiolite, on geochemical constraints, and on the observation of the Hole 1256D cores, France et al. [2009b] proposed a reinterpretation of the initial model presented for IODP Hole 1256D (Figure 1). They proposed that the dike screens could represent xenolith accumulations close to the melt lens floor, hence increasing significantly the amount of stoped material. Microgranular inclusions of clinopyroxenes observed within orthopyroxenes (Figure S4 in the auxiliary material), as well as minerals within large xenoliths follow the general trend formed by granoblastic dikes in the $\mathrm{TiO}_{2}$ versus $\mathrm{Al}_{2} \mathrm{O}_{3}$ diagram (Figure 4a), supporting the assimilation model. Moreover, although assigned to the granoblastic dikes by Teagle et al. [2006], some of the samples of the dike screens show typical magmatic, granular textures very similar to those observed in other domains of the gabbroic section. Characteristic, and different from the granoblastic dikes, are the stability of euhedral orthopyroxene and the presence of numerous of micrometer-sized inclusions in both pyroxenes and even in plagioclases. The observation that many samples of the dike screens display a magmatic rather than a metamorphic texture, implying a direct involvement into magma chamber processes, supports the hypothesis of France et al. [2009b] that the upper and the lower dike screens correspond to stoped xenoliths of partially resorbed granoblastic dikes, which were accumulated in the lower part of the axial melt lens
(Figure 1b), instead of contact-metamorphosed dikes.

[48] Smaller microgranular domains included within gabbros (Figures 2 and 3 ) are partly off the evolution trend granoblastic dikes shown in Figure 4a, and support the hypothesis that these granoblastic fragments have been widely equilibrated with the host magma during the magmatic assimilation process, and that only textural relics from the granoblastic stage are preserved. This is also expressed by the estimated equilibration temperatures that are largely above the solidus of hydrothermally altered dikes determined experimentally by France et al. [2010] (e.g., $1020-1040^{\circ} \mathrm{C}$ for microgranular domains in three different gabbros samples using the 2-pyroxene QUILF thermometer; for details see Table 2). Assimilation of previously altered and metamorphosed dikes appears to be a widespread phenomenon in the axial melt lens.

\subsubsection{Hydrous Partial Melting and Melt Lens Contamination at Fast Spreading Ridges}

[49] Several samples with hornfelsic, microgranular or granoblastic textures located in the upper isotropic gabbro section have been described in the Hole 1256D cores [Teagle et al., 2006; Wilson et al., 2006; Koepke et al., 2008; Alt et al., 2010, France et al., 2009b], at Hess Deep [Gillis, 2008], or in ophiolites [Gillis and Roberts, 1999; Gillis and Coogan, 2002; Gillis, 2008; France et al., 2009b]. These lithologies have been interpreted to represent residual parageneses after a hydrous partial melting event, which is believed to play a significant role in contaminating the upper melt lens [e.g., Coogan et al., 2003; Gillis, 2008; France et al., 2009b, 2010]. However, up to now, direct petrographic or geochemical evidences that hydrous partial melting really occurred are rare, although evidence for hydrous partial melting has been published for deeper horizons in gabbros [Koepke et al., 2005a, 2005b] or in upper mantle/lower crust context [Benoit et al., 1999; Nonnotte et al., 2005]. The different observations presented here shed some light on this process.

[50] A marked feature of both Gabbro 1 and 2 are plagioclases in granular and microgranular domains with uncommon spongy-like textures and zonations. Typical are zones of An-enriched plagioclase that can be interpreted as residual after hydrous partial melting, and more or less rectangular zones filled with Ab-rich plagioclase that would correspond to former melt pools, now frozen. BSE image and related concentration profiles are shown in 
Figure S6 in the auxiliary material for plagioclases from Gabbro 1 and 2. The similarity of the observed structures with those produced by experimental partial melting of plagioclase is striking (Figures S6a and S6b in the auxiliary material) [e.g., Johannes and Holtz, 1992, Figures 6.4, 9.12, and 9.16]. These melting features support a model in which a dynamic melt lens can reheat and partially assimilate either the sheeted dikes root, or previously crystallized gabbros [France et al., 2009b]. Another feature of interest is observed in a gabbro bearing xenoliths with typical microgranular textures (Figure S6c in the auxiliary material; sample 23218285 from Gabbro 2). These xenoliths show plagioclases with characteristic reverse zoning displaying rims that are strongly enriched in An content. An-rich zones are also associated with veins and cracks (Figure S6c in the auxiliary material). Late orthopyroxene can be observed forming rims around olivine grains (Figure S6c in the auxiliary material). Moreover, clinopyroxene and olivines show micrometer-sized oxide inclusion. All these observations are characteristic of hydrous partial melting of gabbros [Koepke et al., 2004, 2005a, 2005b] or of previously hydrothermally altered dikes [France et al., 2010]. Hydrous anatexis of the partially assimilated xenoliths should trigger a contamination in the surrounded melt, which may be recorded in the crystallized gabbro. Models on that [e.g., Gillis and Coogan, 2002; Wanless et al., 2010] supported by experimental studies [France et al., 2009a] have shown that such anatectic melts are REE enriched relative to MORB-type melts. Such enrichment is observed in sample 232_2_98_100, a gabbro which bears dike xenoliths as presented in Figure 3. The trace element composition of clinopyroxenes of the subophitic domain of this gabbro attests to melt lens contamination, at least locally, in areas close to assimilated pieces (see Figure 6d).

[51] Geochemical studies on chlorine contents in MORB strongly support that assimilation is much more pronounced at fast spreading ridges than at slow spreading systems (using $\mathrm{Cl}$ as proxy for contamination [e.g., Michael and Schilling, 1989; Jambon et al., 1995; Michael and Cornell, 1998; Coogan et al., 2003]). This is in agreement with a dynamic behavior of the upper melt lens at fast spreading ridges, resulting in the assimilation of stoped fragments from the base of the sheeted dikes, and contamination of MORB melts by hydrothermal fluids [Coogan et al., 2003; France et al., 2009b]. All analyzed amphiboles of magnesiohastingsitic composition of the granular domains interpreted as primary magmatic (see section 3.1.2) show relative high $\mathrm{Cl}$ contents, between 0.4 and $0.6 \mathrm{wt} \%$, which is significantly higher than those values expected for a pure magmatic source [Coogan et al., 2001; Gillis et al., 2003], and points to a contamination by hydrothermal fluids during the magma evolution.

[52] Contamination of the axial melt lens by assimilation of previously hydrothermally altered rocks is also strongly supported by the comparison of mineral compositions of fast and slow spreading ridge gabbros (Figure 4c). However, it should be noted that the gabbros from Hole 1256D correspond to the highest level in the plutonic oceanic crust, while the trends shown for other localities correspond to deeper levels in the plutonic crust. The addition of hydrous fluids to MORB-type melts triggers a shift to anorthite richer compositions for plagioclases [e.g., Hattori and Sato, 1996; Kuritani, 1998; Kvassnes et al., 2004; Landi et al., 2004; Feig et al., 2006; Cordier et al., 2007; Koepke et al., 2009]. As assimilation has been described in several sites corresponding to fast spreading accretion (EPR, Hess Deep, Hole 1256D, several sites in Oman and Troodos ophiolites), we suggest that this process is common, and could explain the shift of plagioclases from fast spreading ridges to An-richer compositions than for minerals from slow spreading ridges (Figure 4c). However, plagioclase with high anorthite contents could be also caused by a more primitive parental composition. Moreover, the late addition of water by contamination could result in reverse plagioclase zoning with An-richer compositions at the rim, which is not observed in normal oceanic gabbros.

\section{Conclusion}

[53] The IODP Expedition 312 at ODP Site 1256 provided the first continuous in situ sampling of fast spread ocean crust from the extrusive lavas, through the sheeted dikes, and into the uppermost gabbros. The detailed investigation of the petrography and phase chemistry of the recovered gabbros reveals the record of a very complex magmatic history and brings significant insight into the mechanism of melt lens fossilization. The combined results of petrography and microanalysis allow us to interpret the spotty/patchy gabbros as a close association of two different domains crystallized at different evolution stages of the same parental magma by a process of in situ fractionation. The first stage of crystallization (subophitic domain) is in equilibrium with the upper crust lavas and dikes, which also indicates that the axial melt lens does feed the upper crust. 
[54] It is obvious that a given piece of gabbro drilled at Site 1256, typically characterized by a multidomain appearance, does not correspond to a frozen global equilibrium. However, the high grade of correspondence of the observed features and the predicted trends/correlations based on equilibrium processes makes it very probable that at least a local equilibrium was achieved in the individual domains, and that the application of petrological/ geochemical tools established for equilibrium conditions is acceptable.

[55] An open question is whether the 1256D gabbros correspond more to a cumulate rock or to frozen melts. At least for the spotty/patchy gabbros from Gabbro 1 which are characterized by the close association of subophitic and granular domains (Figure S1 in the auxiliary material), it is obvious that these correspond more to frozen melts. Compared to the average composition of basalts and dikes of the upper section, the spotty/patchy gabbros show identical bulk major and minor element compositions (e.g., $\mathrm{MgO}, \mathrm{FeO}, \mathrm{TiO}_{2}, \mathrm{~K}_{2} \mathrm{O}, \mathrm{P}_{2} \mathrm{O}_{5}$ ), only slightly higher concentrations in compatible trace elements $(\mathrm{Ni}, \mathrm{Cr}$ ), and only slightly lower concentrations in incompatible elements ( $\mathrm{Zr}, \mathrm{Y}$; for data see Teagle et al. [2006]). Thus, the interpretation that at least those spotty/patchy gabbros correspond to frozen melts with a negligible cumulate component is valid, which is an important requirement for our model on in situ fractionation.

[56] The first in situ drilling of the complex gabbroic sequence from the root zone of the sheeted dike complex in intact, fast spreading ocean crust also offers new evidences for stoping and assimilation of previously hydrothermalized dikes. Future detailed geochemical and microanalytical investigation should allow to further document this important contamination process, which potentially affect the chemistry of seafloor basalts.

\section{Acknowledgments}

[57] We gratefully acknowledge the Captain and shipboard crew of IODP Expedition 312 for their assistance in data collection at sea. We wish to thank the Scientific Party of IODP Expedition 312 for fruitful discussion during the cruise. Jean-Luc Devidal is thanked for assistance during trace element analysis at LMV. This study used samples provided by the Integrated Ocean Drilling Program. Funding for this research was provided by grants from the Deutsche Forschungsgemeinschaft.

\section{References}

Aigner-Torres, M., J. Blundy, P. Ulmer, and T. Pettke (2007), Laser ablation ICPMS study of trace element partitioning between plagioclase and basaltic melts: An experimental approach, Contrib. Mineral. Petrol., 153, 647-667, doi:10.1007/s00410-006-0168-2.

Alt, J. C., C. Laverne, R. M. Coggon, D. A. H. Teagle, N. R. Banerjee, S. Morgan, C. E. Smith-Duque, M. Harris, and L. Galli (2010), Subsurface structure of a submarine hydrothermal system in ocean crust formed at the East Pacific Rise, ODP/IODP Site 1256, Geochem. Geophys. Geosyst., 11, Q10010, doi:10.1029/2010GC003144.

Anders, E., and N. Grevesse (1989), Abundances of the elements: Meteoritic and solar, Geochim. Cosmochim. Acta, 53, 197-214, doi:10.1016/0016-7037(89)90286-X.

Andersen, D. J., D. H. Lindsley, and P. M. Davidson (1993), QUILF: A pascal program to assess equilibria among $\mathrm{Fe}-\mathrm{Mg}-\mathrm{Mn}$-Ti oxides, pyroxenes, olivine, and quartz, Comput. Geosci., 19, 1333-1350, doi:10.1016/0098-3004 (93)90033-2.

Ariskin, A. A. (1999), Phase equilibria modeling in igneous petrology: Use of COMAGMAT model for simulating fractionation of ferro-basaltic magmas and the genesis of highalumina basalt, J. Volcanol. Geotherm. Res., 90, 115-162, doi:10.1016/S0377-0273(99)00022-0.

Batiza, R., and Y. L. Niu (1992), Petrology and magma chamber processes at the East Pacific Rise $\sim 9^{\circ} 30^{\prime} \mathrm{N}, J$. Geophys. Res., 97, 6779-6797, doi:10.1029/92JB00172.

Benoit, M., G. Ceuleneer, and M. Polvé (1999), The remelting of hydrothermally altered peridotite at mid-ocean ridges by intruding mantle diapirs, Nature, 402, 514-518, doi:10.1038/ 990073.

Berndt, J., J. Koepke, and F. Holtz (2005), An experimental investigation of the influence of water and oxygen fugacity on differentiation of MORB at $200 \mathrm{MPa}$, J. Petrol., 46, 135-167, doi:10.1093/petrology/egh066.

Boudier, F., A. Nicolas, and B. Ildefonse (1996), Magma chambers in the Oman ophiolite: Fed from the top and the bottom, Earth Planet. Sci. Lett., 144, 239-250, doi:10.1016/0012821X(96)00167-7.

Canales, J. P., M. R. Nedimovic, G. M. Kent, S. M. Carbotte, and R. S. Detrick (2009), Seismic reflection images of a near-axis melt sill within the lower crust at the Juan de Fuca ridge, Nature, 460, 89-93, doi:10.1038/nature08095.

Coggon, R. M., J. C. Alt, and D. A. Teagle (2008), Thermal history of ODP Hole 1256D lower sheeted dikes: Petrology, chemistry and geothermometry of the granoblastic dikes, Eos Trans. AGU, 89(53), Fall Meet. Suppl., Abstract V44B-08.

Coogan, L. A. (2007), The lower oceanic crust, in Treatise on Geochemistry, vol. 3, edited by K. Turekian and H. D. Holland, pp. 1-45, Elsevier, Amsterdam, doi:10.1016/ B978-008043751-4/00230-3.

Coogan, L. A., P. D. Kempton, A. D. Saunders, and M. J. Norry (2000a), Melt aggregation within the crust beneath the Mid-Atlantic Ridge: Evidence from plagioclase and clinopyroxene major and trace element compositions, Earth Planet. Sci. Lett., 176, 245-257, doi:10.1016/S0012-821X (00)00006-6.

Coogan, L. A., A. D. Saunders, P. D. Kempton, and M. J. Norry (2000b), Evidence from oceanic gabbros for porous melt migration within a crystal mush beneath the Mid-Atlantic Ridge, Geochem. Geophys. Geosyst., 1(9), 1044, doi:10.1029/ 2000GC000072. 
Coogan, L. A., R. N. Wilson, K. M. Gillis, and C. J. MacLeod (2001), Near-solidus evolution of oceanic gabbros: Insights from amphibole geochemistry, Geochim. Cosmochim. Acta, 65, 4339-4357, doi:10.1016/S0016-7037(01)00714-1.

Coogan, L. A., K. M. Gillis, C. J. MacLeod, G. M. Thompson, and R. Hékinian (2002a), Petrology and geochemistry of the lower ocean crust formed at the East Pacific Rise and exposed at Hess Deep: A synthesis and new results, Geochem. Geophys. Geosyst., 3(11), 8604, doi:10.1029/ $2001 \mathrm{GC} 000230$.

Coogan, L. A., G. Thompson, and C. J. MacLeod (2002b), A textural and geochemical investigation of high level gabbros from the Oman ophiolite: Implications for the role of the axial magma chamber at fast-spreading ridges, Lithos, 63, 67-82, doi:10.1016/S0024-4937(02)00114-7.

Coogan, L. A., N. C. Mitchell, and M. J. O'Hara (2003), Roof assimilation at fast spreading ridges: An investigation combining geophysical, geochemical, and field evidence, J. Geophys. Res., 108(B1), 2002, doi:10.1029/2001JB001171.

Cordier, C., M. Caroff, T. Juteau, C. Fleutelot, C. Hemond, M. Drouin, J. Cotten, and C. Bollinger (2007), Bulk-rock geochemistry and plagioclase zoning in lavas exposed along the northern flank of the Western Blanco Depression (northeast Pacific): Insight into open-system magma chamber processes, Lithos, 99, 289-311, doi:10.1016/j.lithos.2007.06.009.

Dick, H. J. B., and J. H. Natland (1996), Late-stage melt evolution and transport in the shallow mantle beneath the East Pacific Rise, Proc. Ocean Drill. Program Sci. Results, 147, 103-134.

Dick, H. J. B., et al. (2002), Primary silicate mineral chemistry of a $1.5-\mathrm{km}$ section of very slow spreading lower ocean crust: ODP Hole 735B, Southwest Indian Ridge, Proc. Ocean Drill. Program Sci. Results, 176, 1-61.

Donaldson, C. H. (1976), Experimental investigation of olivine morphology, Contrib. Mineral. Petrol., 57, 187-213, doi:10.1007/BF00405225.

Donaldson, C. H. (1977), Laboratory duplication of comb layering in Rhum pluton, Min. Mag., 41, 323-336, doi:10.1180/minmag.1977.041.319.03.

Dziony, W., J. Koepke, and F. Holtz (2008), Data report: Petrography and phase analyses in lavas and dikes from the hole 1256D (ODP Leg 206 and IODP Expedition 309, East Pacific Rise) [online], Proc. Integrated Ocean Drill. Program, 309/312, 22 pp., doi:10.2204/iodp.proc.309312.201. 2008. [Available at http://publications.iodp.org/proceedings/ 309 312/201/201 .htm]

Ernst, W. G., and J. Liu (1998), Experimental phase-equilibrium study of $\mathrm{Al}$ - and $\mathrm{Ti}$-contents of calcic amphibole in MORB - A semiquantitative thermobarometer, Am. Mineral., 83, 952-969.

Faure, F., and P. Schiano (2004), Crystal morphologies in pillow basalts: Implications for mid-ocean ridge processes, Earth Planet. Sci. Lett., 220, 331-344, doi:10.1016/S0012821X(04)00057-3.

Faure, F., G. Trolliard, C. Nicollet, and J. M. Montel (2003), A developmental model of olivine morphology as a function of the cooling rate and the degree of undercooling, Contrib. Mineral. Petrol., 145, 251-263, doi:10.1007/s00410-0030449-y.

Faure, F., N. Arndt, and G. Libourel (2006), Formation of spinifex texture in komatiites: An experimental study, J. Petrol., 47, 1591-1610, doi:10.1093/petrology/eg1021.

Feig, S., J. Koepke, and J. Snow (2006), Effect of water on tholeiitic basalt phase equilibria: An experimental study under oxidizing conditions, Contrib. Mineral. Petrol., 152 , 611-638, doi:10.1007/s00410-006-0123-2.

Feig, S., J. Koepke, and J. E. Snow (2010), Effect of oxygen fugacity and water on phase equilibria of a hydrous tholeiitic basalt, Contrib. Mineral. Petrol., 159, 551-568, doi:10.1007/ s00410-010-0493-3.

France, L. (2009), Magmatic/hydrothermal interactions at fast spreading mid-ocean ridges: Implications on the dynamics of the axial melt lens, Ph.D. thesis, 388 pp., Univ. Montpellier II, Montpellier, France.

France, L., B. Ildefonse, J. Koepke, C. MacLeod, and M. Godard (2009a), Melting the hydrothermally altered sheeted dike complex: Experiments and chemical compositions, Eos Trans. AGU, 90(52), Fall Meet. Suppl., Abstract OS11B-07.

France, L., B. Ildefonse, and J. Koepke (2009b), Interactions between magma and hydrothermal system in Oman ophiolite and in IODP Hole 1256D: Fossilization of a dynamic melt lens at fast spreading ridges, Geochem. Geophys. Geosyst., 10, Q10O19, doi:10.1029/2009GC002652.

France, L., J. Koepke, B. Ildefonse, S. Cichy, and F. Deschamps (2010), Hydrous partial melting in the sheeted dike complex at fast spreading ridges: Experimental and natural observations, Contrib. Mineral. Petrol., 159, 683-704, doi:10.1007/ s00410-010-0502-6.

Gagnon, J. E., B. J. Fryer, I. M. Samson, and A. E. WilliamsJones (2008), Quantitative analysis of silicate certified reference materials by LA-ICPMS with and without an internal standard, J. Anal. At. Spectrom., 23, 1529-1537, doi:10.1039/b801807n.

Garel, E., O. Dauteuil, and Y. Lagabrielle (2002), Deformation processes at fast to ultra-fast oceanic spreading axes: Mechanical approach, Tectonophysics, 346, 223-246, doi:10.1016/ S0040-1951(01)00280-3.

Gillis, K. M. (2002), The rootzone of an ancient hydrothermal system exposed in the Troodos ophiolite, Cyprus, J. Geol., 110, 57-74, doi: $10.1086 / 324205$.

Gillis, K. M. (2008), The roof of an axial magma chamber: A hornfelsic heat exchanger, Geology, 36, 299-302, doi:10.1130/G24590A.1.

Gillis, K. M., and L. A. Coogan (2002), Anatectic migmatites from the roof of an ocean ridge magma chamber, J. Petrol., 43, 2075-2095, doi:10.1093/petrology/43.11.2075.

Gillis, K. M., and M. D. Roberts (1999), Cracking at the magma-hydrothermal transition: Evidence from the Troodos Ophiolite, Cyprus, Earth Planet. Sci. Lett., 169, 227-244, doi:10.1016/S0012-821X(99)00087-4.

Gillis, K. M., L. A. Coogan, and M. Chaussidon (2003), Volatile element $(\mathrm{B}, \mathrm{Cl}, \mathrm{F})$ behaviour in the roof of an axial magma chamber from the East Pacific Rise, Earth Planet. Sci. Lett., 213, 447-462, doi:10.1016/S0012-821X(03)00346-7.

Hattori, K., and H. Sato (1996), Magma evolution recorded in plagioclase zoning in 1991 Pinatubo eruption products, $\mathrm{Am}$. Mineral., 81, 982-994.

Holland, T. J. B., and J. Blundy (1994), Non-ideal interactions in calcic amphiboles and their bearing on amphibole-plagioclase thermometry, Contrib. Mineral. Petrol., 116, 433-447, doi:10.1007/BF00310910.

Hooft, E. E. E., R. S. Detrick, and G. M. Kent (1997), Seismic structure and indicators of magma budget along the southern East Pacific Rise, J. Geophys. Res., 102, 27,319-27,340, doi:10.1029/97JB02349.

Jambon, A., B. Deruelle, G. Dreibus, and F. Pineau (1995), Chlorine and bromine abundance in MORB: The contrasting behaviour of the Mid-Atlantic Ridge and East Pacific Rise 
and implications for chlorine geodynamic cycles, Chem. Geol., 126, 101-117.

Johannes, W., and F. Holtz (1992), Melting of plagioclase in granite and related systems-Composition of coexisting phases and kinetic observations, Trans. R. Soc. Edinburgh Earth Sci., 83, 417-422.

Johnson, M. C., A. T. Anderson, and M. J. Rutherford (1994), Pre-eruptive volatile contents of magmas, in Volatiles in Magmas, Rev. Mineral., vol. 30, edited by M. R. Carroll and J. R. Holloway, pp. 281-330, Mineral. Soc. of Am., Washington, D. C.

Karson, J. A., et al. (2002), Structure of uppermost fast-spread oceanic crust exposed at the Hess Deep Rift: Implications for subaxial processes at the East Pacific Rise, Geochem. Geophys. Geosyst., 3(1), 1002, doi:10.1029/2001GC000155.

Kennedy, A. K., G. E. Lofgren, and G. J. Wasserburg (1993), An experimental study of trace element partitioning between olivine, orthopyroxene and melt in chondrules: Equilibrium values and kinetic effects, Earth Planet. Sci. Lett., 115, 177-195, doi:10.1016/0012-821X(93)90221-T.

Koepke, J., and H. Behrens (2001), Trace element diffusion in andesitic melts: An application of synchrotron X-ray fluorescence analysis, Geochim. Cosmochim. Acta, 65, 1481-1498, doi:10.1016/S0016-7037(01)00550-6.

Koepke, J., J. Berndt, and F. Bussy (2003), An experimental study on the shallow-level migmatization of ferrogabbros from the Fuerteventura Basal Complex, Canary islands, Lithos, 69, 105-125, doi:10.1016/S0024-4937(03)00049-5.

Koepke, J., S. T. Feig, J. Snow, and M. Freise (2004), Petrogenesis of oceanic plagiogranites by partial melting of gabbros: An experimental study, Contrib. Mineral. Petrol., 146, 414-432, doi:10.1007/s00410-003-0511-9.

Koepke, J., S. T. Feig, and J. Snow (2005a), Late stage magmatic evolution of oceanic gabbros as a result of hydrous partial melting: Evidence from the Ocean Drilling Program (ODP) Leg 153 drilling at the Mid-Atlantic Ridge, Geochem. Geophys. Geosyst., 6, Q02001, doi:10.1029/2004GC000805.

Koepke, J., S. T. Feig, and J. Snow (2005b), Hydrous partial melting within the lower oceanic crust, Terra Nova, 17, 286-291, doi:10.1111/j.1365-3121.2005.00613.x.

Koepke, J., D. M. Christie, W. Dziony, F. Holtz, D. Lattard, J. Maclennan, S. Park, B. Scheibner, T. Yamasaki, and S. Yamasaki (2008), Petrography of the dike-gabbro transition at IODP Site 1256 (equatorial Pacific): The evolution of the granoblastic dikes, Geochem. Geophys. Geosyst., 9, Q07O09, doi:10.1029/2008GC001939.

Koepke, J., S. Schoenborn, M. Oelze, H. Wittmann, S. Feig, E. Hellebrand, F. Boudier, and R. Schoenberg (2009), Petrogenesis of crustal wehrlites in the Oman ophiolite: Experiments and natural rocks, Geochem. Geophys. Geosyst., 10, Q10002, doi:10.1029/2009GC002488.

Kuo, L.-C., and J. Kirkpatrick (1982), Pre-eruption history of phyric basalts from DSDP legs 45 and 46: Evidence from morphology and zoning patterns in plagioclase, Contrib. Mineral. Petrol., 79, 13-27, doi:10.1007/BF00376957.

Kuritani, T. (1998), Boundary layer crystallization in a basaltic magma chamber: Evidence from Rishiri Volcano, northern Japan, J. Petrol., 39, 1619-1640, doi:10.1093/petrology/ 39.9.1619.

Kvassnes, A. J. S., A. H. Strand, H. Moen-Eikeland, and R. Pedersen (2004), The Lyngen Gabbro: The lower crust of an Ordovician Incipient Arc, Contrib. Mineral. Petrol., 148, 358-379, doi:10.1007/s00410-004-0609-8.

Lagabrielle, Y., and M.-H. Cormier (1999), Formation of large summit troughs along the East Pacific Rise as collapse cal- deras: An evolutionary model, J. Geophys. Res., 104, 12,971-12,988, doi:10.1029/1999JB900015.

Landi, P., N. Metrich, A. Bertagnini, and M. Rosi (2004), Dynamics of magma mixing and degassing recorded in plagioclase at Stromboli (Aeolian Archipelago, Italy), Contrib. Mineral. Petrol., 147, 629-631, doi:10.1007/s00410-0040578-y.

Laubier, M., T. L. Grove, and C. H. Langmuir (2010), Laser ICP-MS study of trace element partitioning between olivine, plagioclase, orthopyroxene and melt, Abstract V43A-2338 presented at 2010 Fall Meeting, AGU, San Francisco, Calif., 13-17 Dec.

Lippard, S. J., A. W. Shelton, and I. G. Gass (1986), The Ophiolite of Northern Oman. Geol. Soc. Mem., 11, 178 pp.

Lissenberg, C. J., and H. J. B. Dick (2008), Melt-rock reaction in the lower oceanic crust and its implications for the genesis of mid-ocean ridge basalt, Earth Planet. Sci. Lett., 271, 311-325, doi:10.1016/j.eps1.2008.04.023.

Lofgren, G. E. (1976), Nucleation and growth of feldspar in dynamic crystallization experiments, Geol. Soc. Am. Abstr. Programs, 8, 982.

Lofgren, G. E. (1980), Experimental studies on the dynamic crystallization of silicate melts, in Physics of Magmatic Processes, edited by R. B. Hargraves, pp. 487-551, Princeton Univ. Press, Princeton, N. J.

MacLeod, C. J., and G. Yaouancq (2000), A fossil melt lens in the Oman ophiolite: Implications for magma chamber processes at fast spreading ridges, Earth Planet. Sci. Lett., 176, 357-373, doi:10.1016/S0012-821X(00)00020-0.

MacLeod, C. F., F. Boudier, G. Yaouancq, and C. Richter (1996), Gabbro fabrics from ODP Site 894, Hess Deep: Implications for magma chamber processes at the East Pacific Rise, Proc. Ocean Drill. Program Sci. Results, 147, 317-328.

MacLeod, C. J., et al. (2002), Direct geological evidence for oceanic detachment faulting: The Mid-Atlantic Ridge, $15^{\circ}$ $45^{\prime} \mathrm{N}$, Geology, 30, 879-882, doi:10.1130/0091-7613(2002) $030<0879$ :DGEFOD $>2.0 . \mathrm{CO} ; 2$.

Michael, P. J., and W. C. Cornell (1998), Influence of spreading rate and magma supply on crystallization and assimilation beneath mid-ocean ridges: Evidence from chlorine and major element chemistry of mid-ocean ridge basalts, J. Geophys. Res., 103, 18,325-18,356, doi:10.1029/98JB00791.

Michael, P. J., and J.-G. Schilling (1989), Chlorine in midocean ridge magmas: Evidence for assimilation of seawater-influenced components, Geochim. Cosmochim. Acta, 53, 3131-3143, doi:10.1016/0016-7037(89)90094-X.

Miller, D. J., G. J. Iturrino, and N. I. Christensen (1996), Geochemical and petrological constraints on velocity behavior of lower crustal and upper mantle rocks from the fast-spreading ridge at Hess Deep, Proc. Ocean Drill. Program Sci. Results, 147, 477-490.

Müller, W., M. Shelley, P. Miller, and S. Broude (2009), Initial performance metrics of a new custom-designed $\mathrm{ArF}$ excimer LA-ICPMS system coupled to a two-volume laser-alblation cell, J. Anal. At. Spectrom., 24, 209-214, doi:10.1039/ b805995k.

Natland, J. H., and H. J. B. Dick (1996), Melt migration through high-level gabbroic cumulates of the East Pacific Rise at Hess Deep: The origin of magma lenses and the deep crustal structure of fast-spreading ridges, Proc. Ocean Drill. Program Sci. Results, 147, 21-58.

Neo, N., S. Yamazaki, and S. Miyashita (2009), Data report: Bulk rock compositions of samples from the IODP Expedition 309/312 sample pool, ODP Hole 1256D [online], Proc. Inte- 
grated Ocean Drill. Program, 309/312, 24 pp., doi:10.2204/ iodp.proc.309312.204.2009. [Available at http://publications. iodp.org/proceedings/309_312/204/204_htm]

Nicolas, A., F. Boudier, J. Koepke, L. France, B. Ildefonse, and C. Mevel (2008), Root zone of the sheeted dike complex in the Oman ophiolite, Geochem. Geophys. Geosyst., 9, Q05001, doi:10.1029/2007GC001918.

Nicolas, A., F. Boudier, and L. France (2009), Subsidence in magma chamber and the development of magmatic foliation in Oman ophiolite gabbros, Earth Planet. Sci. Lett., 284, 76-87, doi:10.1016/j.epsl.2009.04.012.

Nonnotte, P., G. Ceuleneer, and M. Benoit (2005), Genesis of andesitic-boninitic magmas at mid-ocean ridges by melting of hydrated peridotites: Geochemical evidence from DSDP Site 334 gabbronorites, Earth Planet. Sci. Lett., 236, 632-653, doi:10.1016/j.eps1.2005.05.026.

Perk, N. W., L. A. Coogan, J. A. Karson, E. M. Klein, and H. D. Hanna (2007), Petrology and geochemistry of primitive lower oceanic crust from Pito Deep: Implications for the accretion of the lower crust at the Southern East Pacific Rise, Contrib. Mineral. Petrol., 154, 575-590, doi:10.1007/ s00410-007-0210-z.

Petersen, J. S. (1985), Columnar-dendritic feldspars in the Lardalite Intrusion, Oslo Region, Norway: 1. Implications for unilateral solidification of a stagnant boundary layer, J. Petrol., 26, 223-252.

Pouchou, J. L., and F. Pichoir (1991), Quantitative analysis of homogeneous or stratified microvolumes applying the model "PAP," in Electron Probe Quantification, edited by K. F. J. Heinrich and D. E. Newbury, pp. 31-75, Plenum, New York.

Singh, S. C., G. M. Kent, J. S. Collier, A. J. Harding, and J. A. Orcutt (1998), Melt to mush variations in crustal magma properties along the ridge crest at the southern East Pacific Rise, Nature, 394, 874-878, doi:10.1038/29740.

Singh, S. C., J. S. Collier, A. J. Harding, G. M. Kent, and J. A. Orcutt (1999), Seismic evidence for a hydrothermal layer above the solid roof of the axial magma chamber at the southern East Pacific Rise, Geology, 27, 219-222, doi:10.1130/ 0091-7613(1999)027<0219:SEFAHL>2.3.CO;2.

Sinton, J. M., and R. S. Detrick (1992), Midocean ridge magma chambers, J. Geophys. Res., 97, 197-216, doi:10.1029/ 91JB02508.

Suhr, G., E. Hellebrand, K. Johnson, and D. Brunelli (2008), Stacked gabbro units and intervening mantle: A detailed look at a section of IODP Leg 305, Hole U1309D, Geochem. Geophys. Geosyst., 9, Q10007, doi:10.1029/2008GC002012.
Teagle, D. A. H., J. C. Alt, S. Umino, S. Miyashita, N. R. Banerjee, D. S. Wilson, and the Expedition 309/312 Scientists (2006), Proceedings of the Integrated Ocean Drilling Program, vol. 309/312, Ocean Drill. Program, College Station, Tex., doi:10.2204/iodp.proc.309312.2006.

Teagle, D. A. H., D. S. Wilson, G. D. Acton, and D. A. E. Vanko (2007), Proceedings of the Ocean Drilling Program, Scientific Results, vol. 206, Ocean Drill. Program, College Station, Tex., doi:10.2973/odp.proc.sr.206.2007.

Tegner, C., and J. R. Wilson (1995), Textures in a poikilitic olivine gabbro cumulate - evidence for supercooling, Mineral. Petrol., 54, 161-173, doi:10.1007/BF01162859.

Van Achterberg, E., C. G. Ryan, S. E. Jackson, and W. L. Griffin (2001), Data reduction software for LA-ICP-MS, in Laser Ablation-ICP-Mass Spectrometry in the Earth Sciences: Principles and Applications, Short Course Ser., vol. 42, edited by P. J. Sylvester, pp. 239-243, Mineral. Assoc. of Can., Ottawa.

Van Kan Parker, M., A. Liebscher, D. Frei, J. van Sijl, W. van Westrenen, J. Blundy, and G. Franz (2010), Experimental and computational study of trace element distribution between orthopyroxene and anhydrous silicate melt: Substitution mechanisms and the effect of iron, Contrib. Mineral. Petrol., 159, 459-473, doi:10.1007/s00410-009-0435-0.

Wanless, V. D., M. R. Perfit, W. I. Ridley, and E. Klein (2010), Dacite petrogenesis on mid-ocean ridges: Evidence for oceanic crustal melting and assimilation, J. Petrol., 51, 2377-2410, doi:10.1093/petrology/egq056.

Welsch, B., F. Faure, P. Bachèlery, and V. Famin (2009), Microcrysts record transient convection at Piton de la Fournaise volcano (La Réunion hotspot), J. Petrol., 50, 2287-2305, doi:10.1093/petrology/egp076.

Wilson, D. S., et al. (2006), Drilling to gabbro in intact ocean crust, Science, 312, 1016-1020, doi:10.1126/science.1126090.

Wood, B. J., and J. D. Blundy (1997), A predictive model for rare earth element partitioning between clinopyroxene and anhydrous silicate melt, Contrib. Mineral. Petrol., 129, 166-181, doi:10.1007/s004100050330.

Yamazaki, S., N. Neo, and S. Miyashita (2009), Data report: Whole-rock major and trace elements and mineral compositions of the sheeted dike-gabbro transition in ODP Hole 1256D [online], Proc. Integrated Ocean Drill. Program, 309/312, 31 pp., doi:10.2204/iodp.proc.309312.203.2009. [Available at http://publications.iodp.org/proceedings/309 312/203/203_htm] 